\title{
VOLTAGE-GATED POTASSIUM CHANNELS CONTROL THE GAIN OF ROD-DRIVEN LIGHT RESPONSES IN MIXED-INPUT ON BIPOLAR CELLS
}

\author{
Christina Joselevitch ${ }^{1,2 *}$, Jan Klooster ${ }^{2}$ and Maarten Kamermans ${ }^{2,3}$
}

1. Department of Experimental Psychology, University of São Paulo, São Paulo, Brazil

2. Retinal Signal Processing, The Netherlands Institute for Neuroscience, Amsterdam, The Netherlands

3. Neurogenetics, Academic Medical Center, Amsterdam, The Netherlands

*Present address: Department of Neurobiology \& Behavior, Stony Brook University, Stony Brook, USA.

Abbreviated Title: $\mathrm{K}^{+}$Channels and Gain Control in Goldfish Bipolar Cells

Text Pages: 39, Figures: 11, Tables: 1, Equations: 10

Manuscript: 8,738 words (excluding References, Legends and Tables); Abstract: 233 words; Introduction: 509 words; Discussion: 1212 words.

Author contributions: C.J. and M.K. designed the experiments, C.J. and J.K. performed the experiments, C.J. and M.K. performed the simulations, C.J., J.K. and M.K. wrote the manuscript. All authors approved the final version of the manuscript.

Acknowledgements: This work was supported by Conselho Nacional de Desenvolvimento Científico e Tecnológico (CNPq, 200915/98-3), Fundação de Amparo à Pesquisa do Estado de São Paulo, Brazil (FAPESP, 2010/16469-0), and The European Office of Aerospace Research \& Development (FA8655-05-C-4018). The authors would like to thank Drs. Leon Lagnado, Robert G. Smith and Henrique von Gersdorff for helpful discussions.

Conflict of interest: The authors declare no competing financial interests.

Correspondence: $\underline{\text { m.kamermans@ @ nin.knaw.nl }}$ 


\section{Key Points Summary}

- Here we show that voltage-gated potassium channels can adjust the gain of the rod input to mixed-input $\mathrm{ON}$ bipolar cells and generate a transient signal already at the first visual synapse.

- These channels are activated during the light-induced depolarization, making bipolar cell light responses smaller, faster, and more transient, effects that can be abolished by the $\mathrm{K}^{+}$channel blocker TEA.

- Mathematical simulations suggest that these channels are concentrated at the bipolar cell dendritic tips, close to the site of rod input.

- This kind of gain control happens at all levels in the retina and is especially important for cells that receive mixed input from rods and cones, in order to prevent premature saturation with increasing light levels and remove the temporal redundancy of the photoreceptor signal.

\footnotetext{
Abbreviations List: ACPT-1, (1S,3R,4S)-1-Aminocyclopentane-1,3,4-tricarboxylic acid; BC, bipolar cell; $C_{\mathrm{m}}$, specific membrane capacitance; DAB, diaminobenzidine; DL-AP4, DL-2-Amino-4phosphonobutyric acid; EAAT5, excitatory amino acid (glutamate) transporter $5, E_{\text {cone, }}$, reversal potential of the cone-driven conductance; $E_{\mathrm{K}}$, reversal potential of the potassium conductance; $E_{\text {leak, }}$ reversal potential of the leak conductance; $E_{\text {rod, }}$, reversal potential of the rod-driven conductance; EM, electron microscopy; FWHM, full width at half-maximum; $g_{\text {gap }}$, gap-junctional conductance; HC, horizontal cell; $I_{\text {gap }}$, gap-junctional current; $I_{\mathrm{A}}$, transient voltage-gated potassium current; $I_{\mathrm{KV}}$, voltage-gated potassium current; INL, inner nuclear layer; $I V$, current-voltage relationship; LM, light microscopy; LY, lucifer yellow; mGluR, metabotropic glutamate receptor; mGluR6, metabotropic glutamate receptor 6; NGS, normal goat serum; ONL, outer nuclear layer; ON BC, depolarizing bipolar cell; ON mBC, depolarizing mixed-input bipolar cell; OPL, outer plexiform layer; PB, phosphate buffer; PKC, phosphokinase C; PTX, picrotoxin; $R_{\mathrm{a}}$, specific cytoplasmic resistivity; $R_{\mathrm{in}}$, input resistance; $R_{\mathrm{m}}$, specific membrane resistance; STRY, strychnine; $V_{\text {hold }}$, holding membrane potential; $V_{\text {rest }}$, resting membrane potential; $V_{\text {soma, somatic }}$ membrane potential; $V_{\text {step }}$, voltage step; $V_{\text {tip }}$, membrane potential at the dendritic tips; TRPM1, transient receptor potential channel, type melastatin-1.
} 


\begin{abstract}
To achieve high sensitivity at scotopic levels, vision sacrifices spatial and temporal resolution. The detection of dim light, however, depends crucially on the ability of the visual system to speed up rod signals as they advance towards the brain. At higher light levels, gain control mechanisms are necessary to prevent premature saturation of secondorder neurons. We investigated how goldfish mixed-input $\mathrm{ON}$ bipolar cells (ON mBCs) manage to partially compensate for the intrinsically slow kinetics of rod signals in the dark-adapted state, and at the same time control the gain of rod signals. Rod-driven responses of axotomized $\mathrm{ON} \mathrm{mBCs}$ become faster and more transient than those of rod horizontal cells as stimulus intensity increases. This transientness has a voltagedependency consistent with the activation of a voltage-gated $\mathrm{K}^{+}$conductance. Simulations with NEURON indicate that the voltage-gated $\mathrm{K}^{+}$channels responsible for speeding up responses are concentrated at the distal tips of the bipolar cell dendrites, close to the glutamate receptors. These channels act as a gain control mechanism, by shunting the effect of tonically hyperpolarized rods onto the $\mathrm{ON} \mathrm{mBC}$. Further activation of $\mathrm{K}^{+}$ channels accelerates the $\mathrm{ON} \mathrm{mBC}$ response by decreasing the membrane time constant as light levels increase. Therefore, the presence of voltage-gated $\mathrm{K}^{+}$channels at the dendritic tips of $\mathrm{ON} \mathrm{mBCs} \mathrm{extends} \mathrm{the} \mathrm{dynamic} \mathrm{range} \mathrm{of} \mathrm{these} \mathrm{neurons,} \mathrm{and} \mathrm{at} \mathrm{the} \mathrm{same}$ time generates a transient signal already at the first visual synapse.
\end{abstract}

Keywords: scotopic vision, retina, bipolar cells, rods, potassium channels, gain control 


\section{Introduction}

The visual system needs to signal fast changes in local mean luminance and contrast to cope with the statistics of natural images and eye movements (Rieke and Rudd, 2009). At very dim light levels, vision is limited by fluctuations in photon absorption and quantal release, making integration over time and space a necessity (Balasubramanian and Sterling, 2009); as light levels increase, the temporal redundancy contained in sustained responses can be eliminated by making them transient. However, the makeup of neuronal networks could potentially slow down transmission of signals along the visual pathways. To compensate for delays generated by synaptic transmission and remove temporal redundancy from the neural code, retinal neurons at all layers have therefore several means of making their light responses transient.

Numerous such mechanisms were reported to exist in retinal bipolar cells. At the dendrites, depolarizing $(\mathrm{ON})$ bipolar cells were shown to compensate for their intrinsically slow transduction cascade by $\mathrm{a} \mathrm{Ca}^{2+}$-mediated feedback onto the light-driven conductance (Berntson et al., 2005; Shiells and Falk, 1999; Snellman and Nawy, 2002). Somatodendritic voltage-gated $\mathrm{K}^{+}$channels were shown to decrease the time constant of the cell membrane (Mao et al., 1998; Mao et al., 2002), and in some species voltage-gated $\mathrm{Na}^{+}$channels were also implicated in signal spread within subtypes of ON bipolar cells (Saszik and DeVries, 2012; Zenisek et al., 2001). Finally, mechanisms at the axon terminal, such as amacrine cell feedback (Kaneko and Tachibana, 1987; Shields et al., 2000), $\mathrm{Ca}^{2+}$ spikes (Dreosti et al., 2011; Protti et al., 2000; Zenisek and Matthews, 1997) and different types of feedback onto the voltage gated $\mathrm{Ca}^{2+}$ current (Palmer et al., 2003b; Palmer et al., 2003a), as well as intrinsic properties of the bipolar cell glutamate release (for examples, see Mennerick and Matthews, 1996 and Oesch and Diamond, 2011), would help make its output faster and more transient.

Despite the evidence for distal mechanisms that could potentially generate transientness (Hu and Pan, 2002; Klumpp et al., 1995; Mao et al., 1998; Mao et al., 2002; Pinto and Klumpp, 1998), rod-driven ON bipolar cell responses in some mammalian species are sustained (Euler and Masland, 2000; Oesch and Diamond, 2011). This would argue in favor of speed and transientness being generated at the bipolar cell output. Opposed to mammalian bipolar neurons, which are electrotonically compact (Oltedal et al., 2009; but see Kuo et al., 2016), fish rod-driven bipolar cells are electrically coupled (Arai et al., 2010; Poznanski and Umino, 1997; Saito and Kujiraoka, 1988; Umino et al., 1994), implying considerable signal attenuation and decrease in response speed due to the large capacitance of the coupled network. In fish bipolar cells, therefore, additional mechanisms may be employed to speed up rod-driven signals before they reach the terminal. 
We studied the rod-driven responses of mixed-input $\mathrm{ON}$ bipolar cells (ON mBCs) in the goldfish retina and found that dendritic voltage-gated $\mathrm{K}^{+}$channels shape the kinetics of their light responses from high scotopic to mesopic light levels. These $\mathrm{K}^{+}$ currents speed up rod-driven light responses as light levels increase, reducing hereby temporal redundancy in the $\mathrm{ON} \mathrm{mBC}$ output. 


\section{Methods}

\section{Ethical Approval}

All animal experiments were carried out with permission of the ethical committee of the Royal Netherlands Academy of Arts and Sciences, acting in accordance with the European Communities Council Directive of 24 November 1986 (86/609/EEC).

\section{Retinal Slices}

The procedure for making goldfish retinal slices has been described elsewhere (Joselevitch and Kamermans, 2007). Briefly, adult goldfish (Carassius auratus) in the light phase of their circadian rhythm were dark-adapted for 5-10 minutes prior to decapitation and enucleation under infrared illumination $(\lambda>850 \mathrm{~nm})$. The anterior segment of the eye was removed, and the retina peeled off the pigment epithelium and sclera and placed receptor-side-up onto a piece of filter paper $(13 \mathrm{~mm}$ diameter, $8 \mu \mathrm{m}$ pore size, Millipore, Amsterdam, The Netherlands). Vacuum was applied to the other side of the filter in order to suck away the vitreous and attach the isolated retina firmly to the paper. The retina and the filter were cut in $100-150-\mu m$-thick slices that were subsequently positioned on Vaseline tracks in a superfusion chamber for the electrophysiological experiments or processed for light/ electron microscopy.

\section{Solutions}

The composition of the Ringer's solution was (in $\mathrm{mM}$ ): $102 \mathrm{NaCl}, 2.6 \mathrm{KCl}, 1 \mathrm{CaCl}_{2}$, $1 \mathrm{MgCl}_{2}, 28 \mathrm{NaHCO}_{3}$ and 5 glucose (248 mOsm). The solution was bubbled continuously with $2.5 \% \mathrm{CO}_{2}$ and $97.5 \% \mathrm{O}_{2}$ for a $\mathrm{pH}$ of 7.8. Picrotoxin (PTX, 100-500 $\mu \mathrm{M}$ ) and strychnine (STRY, 5-18 $\mu \mathrm{M}$ ) were added routinely to the control Ringer in order to block all GABAergic and glycinergic inputs to the recorded cells. For local drug delivery, DLAP4 was dissolved in the control solution and pressure-applied locally with a puffer pipette.

The standard pipette solution contained (in $\mathrm{mM}$ ): $0-60 \mathrm{KGlu}$ or $0-94 \mathrm{KF}, 10-50 \mathrm{KCl}$, $1 \mathrm{MgCl}, 0.1 \mathrm{CaCl}_{2}, 10$ ATP-Mg, 1 GTP-Na, $0-10$ cAMP, 0.1 cGMP-Na, 10 BAPTA-K $_{4}, 1$ Lucifer Yellow-K $\mathrm{K}_{2}, 10-50 \mathrm{KOH}$ (for $\mathrm{pH} 7.25$, mOsm 212-273). No differences in cell behavior and/or response properties were observed with respect to these ranges of osmolarities and intracellular solution constituents, probably due to extensive coupling between bipolar cells in the dark-adapted retina (Arai et al., 2010). When needed, intracellular $\mathrm{K}^{+}$channel block was attempted by replacing $\mathrm{K}^{+}$-based salts by equimolar $\mathrm{Cs}^{+}$methanesulfonate and TEACl combinations in the pipette solution. Junction potentials for each pipette solution were calculated after Barry \& Lynch (1991) and Ng \& Barry (1995) and subtracted from the nominal voltage command values before correction for series resistance (see Data Analysis section). All chemicals were supplied by Sigma. 


\section{Optical Stimulator}

The superfusion chamber was mounted on a microscope equipped with infrared $(\lambda>$ $800 \mathrm{~nm}$ ) differential interference contrast optics (Eclipse E600-FN, NIKON, Japan) and the preparation was viewed in a TV monitor by means a $60 \mathrm{x}$ water-immersion objective (N.A. 1.0) and a CCD camera (Philips, The Netherlands).

The light beam from one $400 \mathrm{~W}$ xenon arc and was separated into two optical paths with a beam splitter (Starna, UK). Both light beams passed through a series of neutral density filters (Schott, Germany), double interference filters (Melles Griot B.V., The Netherlands, peak transmission $\lambda \mathrm{s}=400,450,500,550,600,650,700 \mathrm{~nm}, 8 \mathrm{~nm}$ bandwidth), and circular variable neutral density filters (Barr \& Stroud, UK).

Light stimuli were cast onto the retina via two different paths: small stimuli (slits of 50, 100 and $250 \mu \mathrm{m}$ interposed on the optical path) were projected onto the preparation through the objective by means of mirrors and lenses, and a $3.5 \mathrm{~cm}$ field (referred to from now on as "full field") was projected from below through the microscope condenser. Given the dimensions of the preparation, the effective diameter of the full field was equivalent to the width of the slices (3-6 mm). All set-up configurations were calibrated with a radiometer (50-245, irradiance head J1812, Tektronix, UK), and later with a photodiode (BPW34, Siemens, Germany). Cone light responses to stimulation originating from both channels were used as a control for the calibrations. Absolute intensity values are given in $\log$ quanta* $\mu \mathrm{m}^{-2} * \mathrm{~s}^{-1}$.

\section{Electrodes and Recording Set-up}

Patch pipettes were pulled from borosilicate capillaries (Harvard Apparatus Ltd., UK) with a Brown Flaming Puller (P-87, Sutter Instrument Co., Novato, CA) and had impedances between 5 and $15 \mathrm{M} \Omega$ when filled with pipette solution and measured in Ringer's solution. Series resistances ranged from 6 to $33 \mathrm{M} \Omega$ and were corrected for junction potential and series resistance offline (see Data Analysis section). Electrodes were placed in a PCS-5000 micromanipulator (Burleigh Instruments, Inc., Fishers, NY) and connected to an Axopatch 200B Amplifier (Axon Instruments, Inc., Union City, CA). A second PCS-5000 micromanipulator was used to hold the puffer pipettes (manufactured as described above) and perfuse drugs locally by means of computer-controlled air pressure ejection.

Data acquisition and control of the optical stimulator were made by means of a Power 1401 AD/DA converter (Cambridge Electronic Design Ltd., UK) and an MSDOS-based computer system or Signal 3 for Windows (Cambridge Electronic Design Ltd., UK). Voltage-clamp recordings were performed with corrected $V_{\text {hold }}=-70 \mathrm{mV}$. 
$\mathrm{ON}$ mBCs were visually selected based on their characteristic morphology and position in the outer part of the inner nuclear layer. Cell type was confirmed by measurement of response properties. Lucifer yellow was routinely included in the pipette solutions and dye-filled cells were observed immediately after the experiment. Data from both intact and axotomized cells were used. Unless otherwise stated, recordings from at least three cells yielded similar results for the experiments described.

\section{Data Analysis}

Current transients were used to calculate series and input resistances. Current relaxations to $-10-\mathrm{mV}$ voltage steps from a holding potential of $-70 \mathrm{mV}$ were subtracted from the holding current and fit by double exponential functions of the form

$$
A(\mathrm{t})=A_{0}+A_{1} \cdot \mathrm{e}^{-t / \tau_{1}}+A_{2} \cdot \mathrm{e}^{-t / \tau_{2}}
$$

where $A_{0}$ is the amplitude of the steady-state current at the end of the voltage step, $A_{1}$ and $A_{2}$ are the amplitudes of the two exponentials at the instant of voltage change, and $\tau_{1}$ and $\tau_{2}$ are the corresponding time constants of the current decay towards $A_{0}$ (Mennerick et al., 1997; Nadeau and Lester, 2000). Fits begun 35-45 $\mu$ s after the voltage change to avoid contamination by residual system filtering and extrapolated back to the onset of the voltage step in order to estimate the instantaneous current $\left(A_{0}+A_{1}+A_{2}\right)$. The calculated curves were subtracted from the data and the residual plots were used to control the quality of the fits (Ellis and Duggleby, 1978; Mennerick et al., 1997).

Series resistances were then calculated using the equation (Nadeau and Lester, 2000)

$$
R_{\text {series }}=\left(\frac{V_{\text {step }}}{A_{0}+A_{1}+A_{2}}\right)
$$

where $R_{\text {series }}$ is the series resistance, and $V_{\text {step }}$ is the applied voltage-clamp step. The voltage error for each recording was calculated offline according to the formula

$$
V_{\text {error }}=R_{\text {series }} \cdot A_{0} \text {, }
$$

and subtracted from the nominal command voltages subsequently. Input resistances $\left(R_{\text {in }}\right)$ were estimated using the equation

$$
R_{\text {in }}=\left(\frac{V_{\text {step }}}{A_{0}}\right)-R_{\text {series }} \text {. }
$$

Voltage-gated currents were isolated by means of leak subtraction: the corrected whole-cell $I V$ curves were subtracted from linear regressions of the current traces to voltage steps below $-70 \mathrm{mV}$. Other forms of data analysis are mentioned in the text and figure legends. 


\section{Anatomical Reconstruction}

A retinal slice containing a Lucifer Yellow-filled $\mathrm{ON}$ mBC was fixed for 10 minutes at room temperature in $0.1 \mathrm{M}$ phosphate-buffered ( $\mathrm{pH}$ 6.5) $4 \%$ paraformaldehyde solution, washed in phosphate-buffered saline (PBS) for 10 minutes $(2 \mathrm{x})$, and blocked in $2 \%$ normal goat serum (NGS, Jackson ImmunoResearch Lab, West Grove, PA) in PBS for $20 \mathrm{~min}$ (Fig. 1A). The tissue was mounted on a poly-L-lysine coated slide (Menzel Gläser, Germany) and incubated overnight with a polyclonal antibody against Lucifer Yellow (anti-Lucifer Yellow, rabbit polyclonal, Millipore, 1:3000) at $4^{\circ} \mathrm{C}$ in PBS containing $0.3 \%$ Triton X-100 and 5\% NGS. After washing (15 min, 3x, in PBS), the section was incubated in the secondary antibody (goat anti-rabbit Cy3, Jackson ImmunoResearch Lab, West Grove, PA; 1:500) for 30 minutes. The slide was coverslipped with Vectashield (Vector Labs, Burlingame, CA) and observed on an inverted Zeiss Axiovert $100 \mathrm{M}$ microscope equipped with the LSM 510 META laser scanning confocal module (Zeiss, Germany). Light micrographs were acquired as TIFF files directly from the microscope.
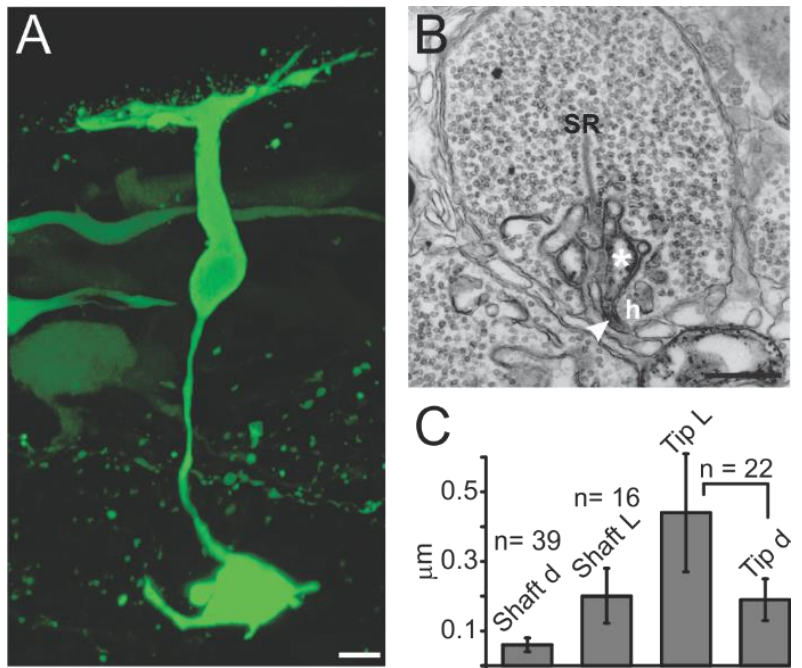

Figure 1. Anatomical reconstruction of a goldfish $\mathrm{ON} \mathrm{mBC}$.

A) Lucifer-Yellow filled cell used for 3D reconstruction. Scale bar $=5 \mu \mathrm{m}$.

B) EM picture of a rod terminal with PKC-immunoreactive processes used for estimating ON $\mathrm{mBC}$ dendritic and tip dimensions. Arrowhead $=$ PKC-positive dendrite invaginating at the rod hilus $(h)$; asterisk $=$ dendritic tip of the same process opposite to a synaptic ribbon $(S R)$. Scale bar $=500 \mathrm{~nm}$.

C) Mean values ( $\pm \mathrm{SD}$ ) for the diameter of PKC-positive processes at the rod hilus ( shaft d, $\mathrm{n}=39$ ), the length of these processes (shaft $L, \mathrm{n}=16$ ), the diameter of PKC-positive dendritic tips opposite to synaptic ribbons (tip $d, \mathrm{n}=22$ ) and the lengths of the same tips (tip $L, \mathrm{n}=22$ ). All values are corrected assuming homogeneous shrinkage of $10 \%$ due to fixation and dehydration.

The TIFF files were then examined with the 3D-analysis software Image Pro (Media Cybernetics, Inc., Rockville, MD), and the diameters, lengths and 3D coordinates 
of the different compartments of the $\mathrm{ON} \mathrm{mBC}$ were measured by means of a homemade analysis tool (NeuralDraw, written by Koos de Vos, The Netherlands Institute for Neuroscience). Because of the diminutive dimensions of the invaginating dendrites contacting rods, estimations of their diameters were made by means of measuring processes in 15 electronmicrographs of dendrites positively labeled for phosphokinase $\mathrm{C}$ (PKC), a marker for rod-driven ON bipolar cells (Fig. 1B and C). The starting values for the secondary dendrites and dendritic tips at cone terminals were obtained from a previous report (mb2s, Ishida et al., 1980). The parameters obtained from this analysis and used in the mathematical model (described in the next section) are listed in Table 1.

Table 1: Dimensions of goldfish ON mBC compartments.

\begin{tabular}{cccc}
\hline Compartment & Length $(\mu \mathbf{m})$ & Diameter $(\mu \mathbf{m})$ & Source \\
\hline Soma & 14 & 7 & Fig. 1A \\
Axon & 40 & 1 & Fig. 1A \\
Axon terminal & 7 & 7 & Fig. 1A \\
Primary dendrites & 26 & 1.3 & Fig. 1A \\
Secondary dendrites & 2 & $0.1 *$ & Ishida et al. $1980^{* *}$ \\
Dendritic shaft & $0.2^{* * *}$ & $0.06^{*}$ & EM pictures \\
Dendritic tip at rod terminals & 0.44 & 0.19 & EM pictures \\
Dendritic tip at cone terminals & 0.17 & 0.17 & Ishida et al. $1980^{* *}$ \\
$*$ These values were varied in some simulations due to the uncertainty inherent to the morphological \\
data. \\
$* *$ Values correspond to those reported for type 2 ON mBCs $($ mb2s).
\end{tabular}

\section{Electron Microscopy}

The same fixation was used as described for light microscopy. Transverse frozen sections, 30-40 $\mu \mathrm{m}$ thick, were obtained on a freezing microtome and collected in phosphate buffer (PB) at room temperature, which is equivalent to freeze-thawing. Retinal sections were incubated for $72 \mathrm{~h}$ with diluted antisera (anti-PKC, 1:400, mouse monoclonal, Sigma). After rinsing, the tissue was incubated in a Poly-HRP-goat anti-mouse IgG (PowerVision, ImmunoVision Technologies Co., Springdale, AR). To visualize the peroxidase, the material was incubated in a Tris- $\mathrm{HCl}$ diaminobenzidine (DAB, 0.05\%) solution containing $0.03 \% \mathrm{H}_{2} \mathrm{O}_{2}$. The DAB reaction product was subsequently intensified by the gold-substituted silver peroxidase method (Gorcs et al., 1986).

Sections were rinsed in sodium cacodylate buffer $0.1 \mathrm{M}(\mathrm{pH} 7.4)$ and post-fixed for $20 \mathrm{~min}$ in $1 \% \mathrm{OsO}_{4}$ supplemented with $1.5 \%$ potassium ferricyanide in sodium cacodylate buffer. After rinsing in sodium cacodylate buffer, the material was dehydrated and embedded in epoxy resin. Ultrathin sections were observed in a Philips EM201 electron microscope (Philips, The Netherlands) and/or Technai (CM) 12 electron microscope (FEI, The Netherlands). Sections examined with the Philips electron microscope were counter-stained with uranyl acetate and lead citrate. 


\section{Sampling and Production of Photomicrographs}

At least 20 retinal sections obtained from a minimum of five animals were used for a given experiment. About five photomicrographs were taken from the most representative sections in each experiment. Light micrographs were acquired as TIFF files from the Zeiss LSM 510 META (1048x1024 pixels, 72 ppi). For EM experiments, the same number of retinal sections/animals was examined at the LM level; labeled sections were chosen for ultra-thin sectioning. A minimum of 40 photoreceptor terminals were observed per ultra-thin section. Ten to 30 micrographs were taken from these sections, depending on the presence and amount of labeling.

Electron micrographs obtained with the FEI electron microscope were directly acquired as TIFF files (1024x1024 pixels, 72 ppi). Electron micrographs obtained from the Philips electron microscope were first printed from the negatives for analysis. The negatives of the prints that were selected for publication were scanned on a sprint scan 4000 scanner (Polaroid, Breda, The Netherlands) and acquired as TIFF files at 600 ppi. All TIFF files were resampled at 400 ppi and subsequently resized and optimized for brightness and contrast using Photoshop (Adobe Systems).

\section{Computer Simulations}

Modeling was carried out using NEURON 6.1.2 (Hines and Carnevale, 1997; Hines and Carnevale, 2000) running on Windows XP, Vista or 7. Integration time steps ranged from 0.00625 to $0.025 \mathrm{~ms}$. The $\mathrm{ON} \mathrm{mBC}$ compartmental model had 7 main parts, subdivided in a total of 495 sections (Fig. 2A): (i) the soma (divided in 11 segments), (ii) the axon (11 segments), (iii) axon terminal (one segment), (iv) six primary dendrites (9 segments each), (v) 162 secondary dendrites ( 9 segments each), (vi) the shafts of the dendritic tips (three segments each), and (vii) the tips of the secondary dendrites (one segment each). To test for spatial accuracy, we compared the kinetics of this model with those of a similar model in which the number of segments was multiplied by three at all sections, which would reduce spatial errors by a factor of nine (Carnevale and Hines, 2006); increasing the number of segments does not change the results described here.

Six primary (thick) dendrites sprouted from the soma of the $\mathrm{ON} \mathrm{mBC}$; each primary dendrite had 27 secondary (thin) dendrites attached to it: two contacting cones and 25 contacting rods, with a total of 12 cones and 150 rods projecting to the cell via the tips of the secondary dendrites. These numbers were chosen such as to yield a rod:cone ratio of 12.5 , close to the value reported in literature for the goldfish mb2 (12.6, Ishida $e t$ $a l ., 1980)$. The total number of photoreceptors in the model (162) is however smaller than the one reported for intact cells (approximately 240), to account for loss of dendrites during the slicing procedure. 

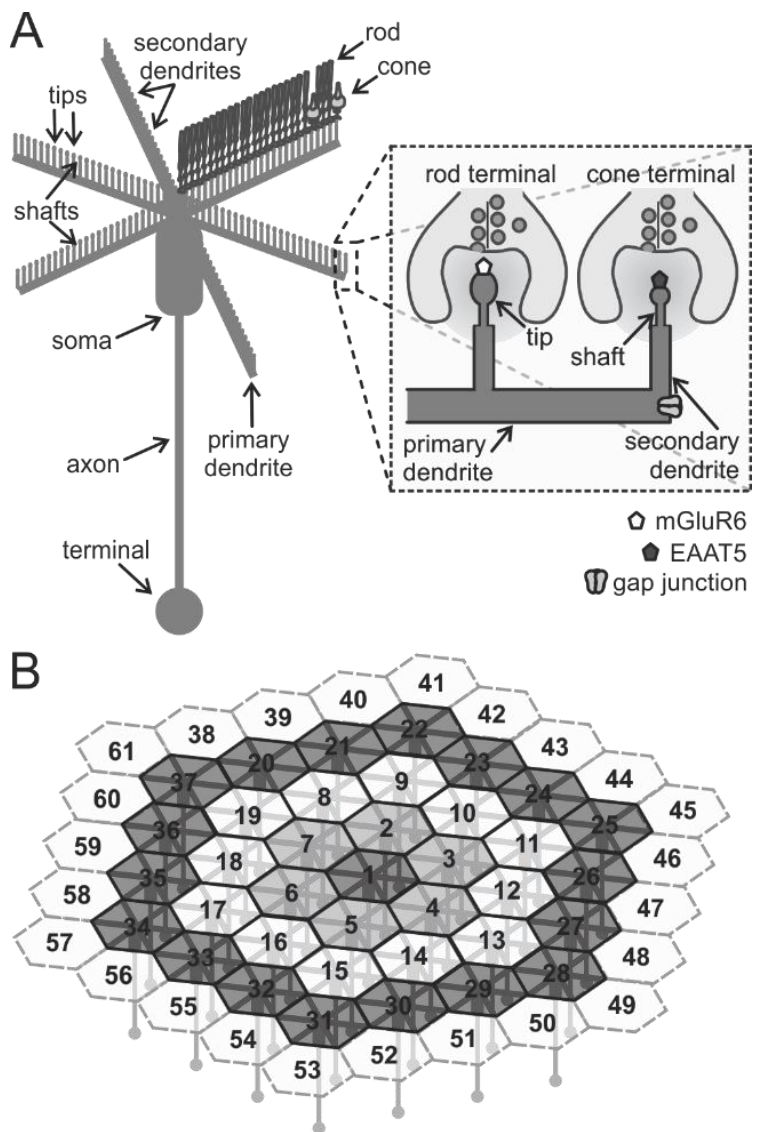

Figure 2. Schematic representation of the model ON mBC network.

A) Schematic of the main compartments: axon terminal, axon, soma, primary dendrites, secondary dendrites, dendritic shafts, and tips (the three latter are not drawn to scale). Each primary dendrite contacts 25 rods and 2 cones (depicted in one of the primary dendrites as an example). The area within the dashed square is enlarged to show the position of the synaptic receptors at the tips of the dendrites and the extrasynaptic receptors at the secondary dendrites. Rods drive a conductance with $E_{\text {rod }}=0 \mathrm{mV}$ (mGluR6), whereas cones drive a conductance with $E_{\text {cone }}=$ $60 \mathrm{mV}$ (EAAT5). Gap junctions between $\mathrm{ON} \mathrm{mBCs}$ are at the extremities of the primary dendrites.

B) Organization of the coupled syncytium. A central ON mBC (1) is connected to three rings of cells in a hexagonal lattice. The outer ring is connected to $\mathrm{mBCs}$ kept at $V_{\text {rest }}$ (dashed hexagons).

ON mBC membrane parameters, such as cytoplasmic resistivity $\left(R_{\mathrm{a}}=250 \Omega * \mathrm{~cm}\right.$, Mennerick et al., 1997), input resistance $\left(R_{\text {in }}\right)$, specific membrane resistance $\left(R_{\mathrm{m}}=\right.$ $\left.67 \mathrm{k} \Omega * \mathrm{~cm}^{2}\right)$ and specific membrane capacitance $\left(C_{\mathrm{m}}=1 \mu \mathrm{F} / \mathrm{cm}^{2}\right)$ were assumed to be uniform throughout the cell, with a passive reversal potential of $E_{\text {leak }}=-80 \mathrm{mV}$ and a potassium equilibrium potential of $E_{\mathrm{K}}=-95 \mathrm{mV}$. Rods and cones, which provide synaptic input to the $\mathrm{ON} \mathrm{mBC}$, were modeled as 3-compartment cells (soma, axon and axon terminal, one segment each) with only passive conductances $\left(R_{\mathrm{a}}=123 \Omega * \mathrm{~cm}, C_{\mathrm{m}}=\right.$ $\left.10 \mu \mathrm{F} / \mathrm{cm}^{2}, R_{\mathrm{m}}=1000 \Omega * \mathrm{~cm}^{2}, E_{\text {leak }}=-50 \mathrm{mV}\right)$.

Control of photoreceptor membrane potential was achieved by means of a simulated somatic voltage-clamp. Photoreceptor inputs were built such that rod hyperpolarization would drive a conductance increase in $\mathrm{ON} \mathrm{mBC}$ with reversal potential 
$E_{\text {rod }}=0 \mathrm{mV}$, and cone hyperpolarization would drive a conductance decrease with $E_{\text {cone }}$ $=-60 \mathrm{mV}$ (Grant and Dowling, 1995; Grant and Dowling, 1996). Synaptic conductances activated by photoreceptor polarization were simulated to yield light responses of physiological amplitudes and a resting membrane potential of around $-24 \mathrm{mV}$ in the absence of $\mathrm{K}^{+}$conductances: the rod-driven synaptic conductance density was $125 \mathrm{nA} / \mathrm{cm}^{2}$ in darkness and $-300 \mathrm{nA} / \mathrm{cm}^{2}$ in light, and the cone-driven synaptic conductance density was kept at $300 \mathrm{nA} / \mathrm{cm}^{2}$.

In order to study the spatial dependence of the $\mathrm{ON} \mathrm{mBC}$ responses, which are electrically coupled in the dark-adapted state (Poznanski and Umino, 1997; Yamada and Saito, 1997), the model cell was connected via the primary dendrite to a ring of 6 other neurons, and these were in turn connected to three concentric rows of cells, yielding a lattice of 61 cells (Fig. 2B). This number of coupled cells was chosen such that the receptive field of the central neuron was not disturbed by border effects: the ON mBCs in the outer ring (dashed hexagons in Fig. 2B) were kept at their resting membrane potential $\left(V_{\text {rest }}=-43 \mathrm{mV}\right)$, such that only the 37 innermost cells would effectively be polarized by current injection in the central neuron. The gap junctional current was simulated using the equation

$$
I_{\text {gap ij }}=g_{\text {gap }} \cdot\left(V_{\mathrm{j}}-V_{\mathrm{i}}\right),
$$

where $I_{\mathrm{gap}}$ ij is the gap junctional current flowing from the pre-synaptic cell to the postsynaptic cell, $g_{\text {gap }}$ is the gap junctional conductance, $V_{\mathrm{i}}$ is the membrane potential of the post-synaptic cell, and $V_{\mathrm{j}}$ is the membrane potential of the pre-synaptic cell.

Voltage-gated $\mathrm{K}^{+}$conductances $\left(I_{\mathrm{KV}}\right)$ were simulated as Hodgkin-Huxley delayed rectifier $\left(m^{3 *} h\right)$ currents (Fig. 3C, D and E). The location of $\mathrm{K}^{+}$channels and their density were varied to reproduce the experimental data. Parameters were chosen such as to yield a voltage activation range and activation time constants similar to those recorded in real cells (Fig. 3A-B and E). However, due to the severe distortion of the $I V$ relation and dynamic properties that remote conductances suffer when measured in non-spherical structures such as a bipolar cell (Hausser and Roth, 1997; Schaefer et al., 2003; Spruston et al., 1993), no further attempt was made to match the kinetics of the modeled currents to those measured in real cells.

\section{Statistics}

Measured parameters were compared by means of one-way ANOVAs and bicaudal Student's T-Tests with Bonferroni correction whenever applicable. Statistical significance was set at $\mathrm{P} \leq 0.05$. 

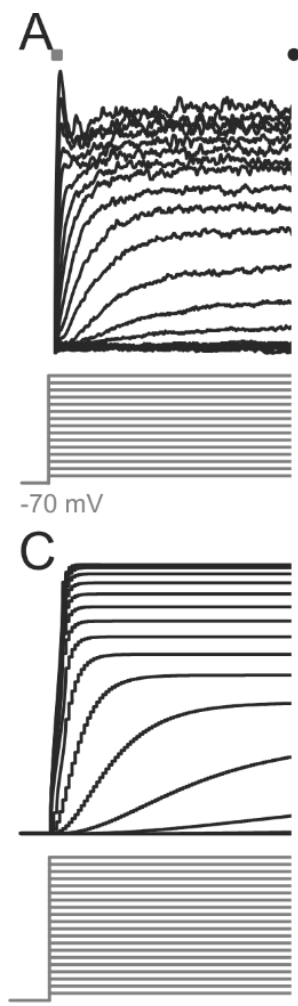

$-100 \mathrm{mV}$
B

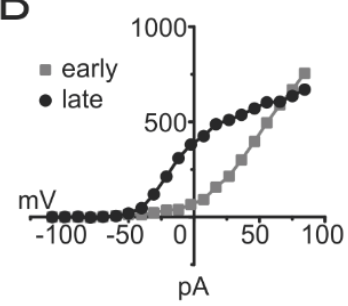

D
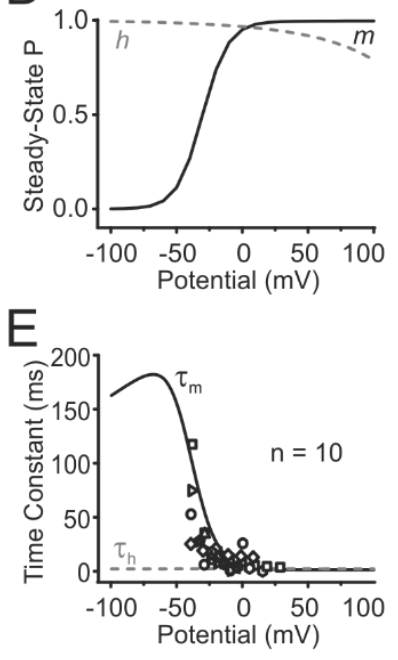

Figure 3. Native $\mathrm{ON} \mathbf{m B C}$ voltage-gated $\mathrm{K}^{+}$currents and the model $I_{\mathrm{Kv}}$.

A) Currents evoked in an $\mathrm{ON} \mathrm{mBC}$ by 80 -ms voltage steps from a holding potential of $-70 \mathrm{mV}$, in $10 \mathrm{mV}$ increments (black traces, top panel). The voltage-clamp protocol is shown in grey below the current traces. In this fast time scale, voltage-dependent outward currents have an early transient component (grey square) and a sustained component that inactivates little (black circle).

B) Leak-subtracted $I V$-relations measured from the traces in (A) at the times indicated by the grey square and black circle. The transient component (grey squares) activates at potentials outside the physiological working range of the cell $(-60$ to $-10 \mathrm{mV})$, whereas the sustained component (black circles) is active within this range.

C) Responses of the model (black traces, top panel) to voltage steps from -90 to $100 \mathrm{mV}$ from a holding potential of $-100 \mathrm{mV}$ (grey lines, bottom panel). The clamped structure is an isolated $\mathrm{ON} \mathrm{mBC}$ axon terminal, with $I_{\mathrm{KV}}$ conductance density $=100 \mathrm{pS} / \mu \mathrm{m}^{2}$.

D) Probability of steady-state activation ( $m$, solid black line) and inactivation ( $h$, dashed grey line) of the modeled currents. $\boldsymbol{E}$, Time constant of activation ( $\tau_{\mathrm{m}}$, solid black line) and inactivation ( $\tau_{\mathrm{h}}$, dashed grey line). Open symbols are activation time constants obtained from exponential fits to voltage-clamp data of 10 goldfish $\mathrm{ON} \mathrm{mBCs}$ measured in retinal slices. 


\section{Results}

\section{Characterization of $O N \mathrm{mBC}$ Rod-Driven Responses}

Inputs from rods and cones are mediated by different mechanisms in fish ON mBCs: cone-driven light responses use glutamate transporters (EAATs, Grant and Dowling, 1996; Wong et al., 2005), whereas the rod-driven conductance is similar to that shown in the mammalian retina and is probably mediated by mGluR6 (Nawy and Copenhagen, 1987; Falk, 1988) and TRPM1 (Shen et al., 2009). To isolate the rod input to ON mBCs, we worked under dark-adapted conditions and used dim light stimuli that do not stimulate cones. In these circumstances, the spectral sensitivity of $\mathrm{ON}$ mBCs follows the rod absorption spectrum (Fig. 4A) and their absolute sensitivity is higher than that of cones (Joselevitch and Kamermans, 2007), indicating that their light responses are rod-driven.

These rod-driven light responses are completely suppressed by group III mGluR agonists such as DL-AP4 or ACPT-1 (Fig. 4B) suggesting that they are solely mediated by mGluR6, as previously demonstrated in the mammalian retina (Slaughter and Miller, 1981; Yamashita and Wassle, 1991). Light responses of mammalian rod bipolar cells, however, were shown to be sustained (Euler and Masland, 2000; Oesch and Diamond, 2011, but see Berntson et al., 2005 and below), whereas those of ON mBCs become transient as intensity increases (Fig. 4C). To elucidate the functional consequences of this behavior, we measured the intensity-response relations early (150-250 ms) and late (400$500 \mathrm{~ms}$ ) in the light response (solid and open circles in Fig. 4C-D, respectively), fitted Hill functions (grey curves in Fig. 4D) through these relations and determined their maximal response amplitudes $\left(V_{\max }\right)$ and slope $(n)$. The maximal amplitude (Fig. 4D, arrow, and Fig. 4E) was higher in the early phase compared to the late phase $\left(\mathrm{P}=4^{*} 10^{-}\right.$ ${ }^{5}$ ), with no significant variation in slope (Fig. $\mathbf{4 F}$ ). The change in response amplitude in time is equivalent to a temporal modulation of the rod-ON mBC synapse.

Time- and Voltage-Dependent Changes in Rod-Driven Responses Are Due to ON mBC Intrinsic Properties

We subsequently investigated the mechanism underlying this transientness. To exclude a contribution of $\mathrm{Ca}^{2+}$ feedback onto the glutamate-gated channels (Berntson et al., 2005; Shiells and Falk, 1999; Snellman and Nawy, 2002), we added $10 \mathrm{mM}$ of the $\mathrm{Ca}^{2+}$ buffer 1,2-bis(o-aminophenoxy)ethane-N,N,N',N'-tetraacetic acid (BAPTA) to the patch pipette solution (Berntson et al., 2005). Since under these conditions both intact ( $n=13$ cells, 20 response families) and axotomized cells ( $n=13,18$ response families) still present transient light responses, we conclude that this transientness was unrelated to $\mathrm{Ca}^{2+}$ dependent processes or conductances located at the axon terminal. That left the somatodendritic compartment as a possible location, or the rod output itself. The latter option was studied next. 

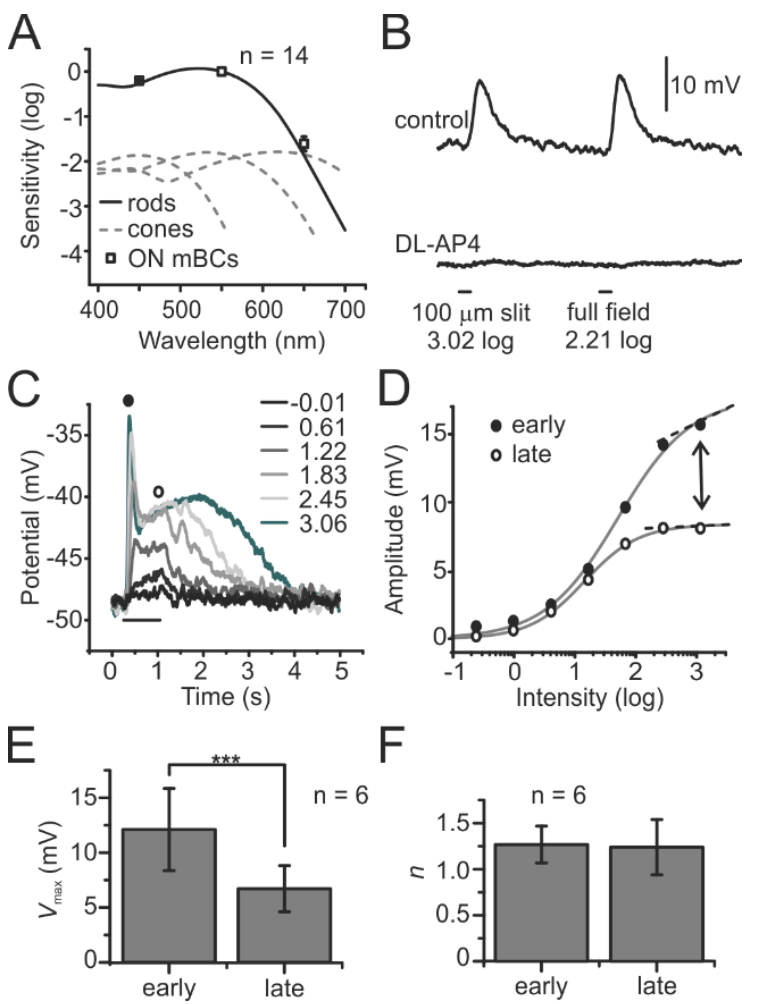

F

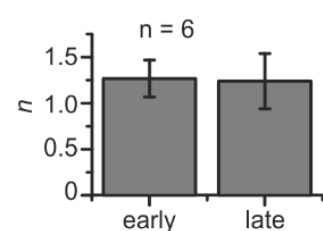

Figure 4. Characterization of rod-driven light responses in goldfish $\mathrm{ON}$ mBCs.

A) $\mathrm{ON}$ mBCs are solely driven by rods in the dark-adapted retina. The mean $( \pm \mathrm{SD})$ spectral sensitivity of dark-adapted $\mathrm{ON}$ mBCs follows the rod absorption spectrum (black line), and their absolute sensitivity is higher than that of S-, L- and M-cones (dashed grey lines). The stimulus was a $100 \mathrm{~ms}$ full-field light flash. $\mathrm{ON} \mathrm{mBC}$ spectral sensitivity data was normalized to the rod peak sensitivity, cone spectra normalized to $\mathrm{ON}$ mBC sensitivity after measurements in 18 goldfish cones (Joselevitch and Kamermans, 2007). Photoreceptor spectra after Mooij \& Van den Berg (1983).

B) Rod-driven light responses are mediated by a group III mGluR. Bath application of $250 \mu \mathrm{M}$ DLAP4 hyperpolarized an $\mathrm{ON} \mathrm{mBC}$ by $24 \mathrm{mV}$ and completely suppressed the responses to $100 \mathrm{~ms}$ light flashes at $550 \mathrm{~nm}$. Stimulus timing and intensity depicted in the figure. Similar results were obtained from 48 cells (DL-AP4, $n=44$ cells; ACPT-1, $n=4$ ).

C) Rod-driven responses adapt during a light stimulus. Voltage responses of an axotomized ON $\mathrm{mBC}$ to $800 \mathrm{~ms}$ light stimuli of increasing intensities at $550 \mathrm{~nm}$. Stimulus timing and intensity depicted in the figure. As intensity increases, light responses start displaying an initial transient peak (black circle) and a sustained plateau (open circle) at a more hyperpolarized level.

D) Intensity-response relations of the cell in (C) measured at the times indicated by the black (early) and open (late) circles, respectively. At low intensities, there is little difference between the early and late components of the light response, whereas at higher intensities response amplitudes of the late component are smaller (arrow). Solid grey curves are Hill fits to the data points to obtain values for maximal response amplitudes $\left(V_{\max }\right)$, sensitivity $(K)$ and slope $(n)$ of the curves.

E) $V_{\max }$ (means $\pm \mathrm{SD}$ ) obtained in 6 axotomized cells ( 9 response families) for the same protocol as in $(\mathrm{C})$.

F) Slopes (means \pm SD) obtained in 6 axotomized cells (9 response families) for the same protocol as in (C).

Although the rod-driven light responses of $\mathrm{ON} \mathrm{mBCs}$ become transient with increasing intensity (Fig. 5A), this does not happen with responses of rod-driven horizontal cells (Fig. 5B). Since horizontal cells sense express AMPA-type glutamate receptors, which are much faster than the metabotropic receptors expressed in $\mathrm{ON} \mathrm{mBCs,}$ 
these results suggest that the rod input to $\mathrm{ON}$ mBCs is sustained and does not become transient with increasing intensity. Therefore, the mechanism generating the transientness of rod-driven $\mathrm{ON} \mathrm{mBC}$ responses must be intrinsic to bipolar cells.
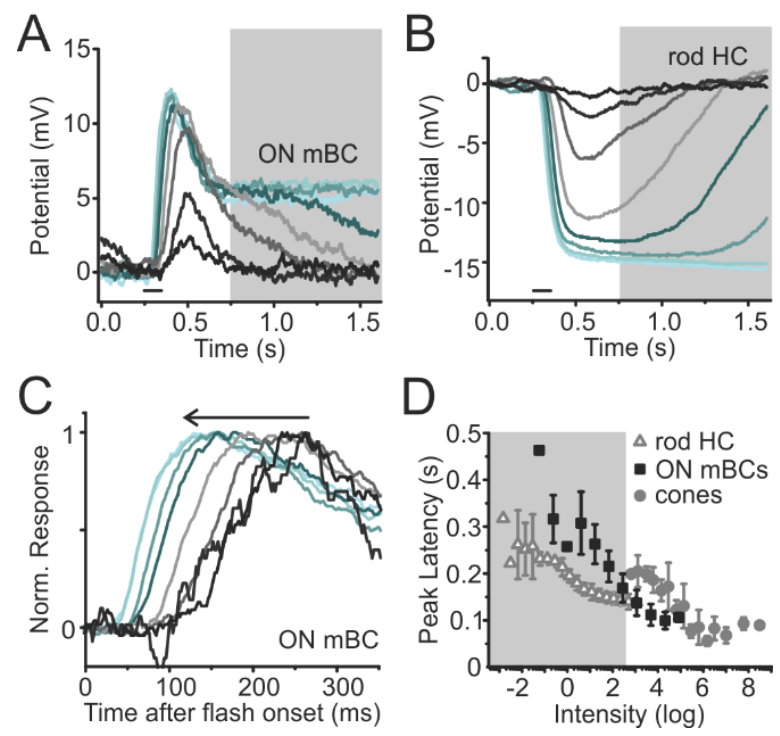

Figure 5. ON mBC light response kinetics derive from intrinsic properties.

A) Responses of an $\mathrm{ON} \mathrm{mBC}$ to $100 \mathrm{~ms}$ full-field light stimulation of increasing intensities at $550 \mathrm{~nm}$ (Intensities: $1.26,1.92,2.59,3.26,3.93,4.57,5.22$ and $5.55 \log$ quanta* $\mu \mathrm{m}^{-2 *} \mathrm{~s}^{-1}$ ). Stimulus timing depicted in the picture (black bar). As light intensity increases, a plateau with smaller amplitude develops after cessation of the light stimulus (shaded area).

B) Rod-driven horizontal cell responses to the same stimuli as in (A) are sustained (shaded area), indicating that the output of goldfish rods to second-order neurons does not become transient with increasing light intensities.

C) $\mathrm{ON} \mathrm{mBC}$ responses become faster at higher light levels. Same responses of the cell in (A) in a faster time scale to show that as stimulus intensity increases, the cell reaches its maximal response sooner.

D) Mean peak latency ( $\pm \mathrm{SD}$ ) for $6 \mathrm{ON} \mathrm{mBCs} \mathrm{(10} \mathrm{response} \mathrm{families),} 1$ rod-driven $\mathrm{HC}$ ( 2 response families) and 7 cones (16 response families) for stimuli of increasing intensities at $550 \mathrm{~nm}$. Peak latencies were measured from Boltzmann fits to the data; responses were considered to have reached their peak at $90 \%$ of the curve maximum. The shaded area indicates intensities to which only rods are sensitive.

Not only do $\mathrm{ON} \mathrm{mBC}$ responses become more transient with increasing light intensities, they also become substantially faster (Fig. 5C, arrow). Fig. 5D shows that this holds for $\mathrm{ON} \mathrm{mBCs}$, rod-driven horizontal cells and cones. To determine whether the reduction in time to peak originated in the photoreceptors, we plotted the peak latency for all three cell types as function of intensity and determined the slope of these curves, the temporal gain. The slopes were $62 \pm 14 \mathrm{~ms} / \mathrm{log}$ quanta* $\mu \mathrm{m}^{-2} * \mathrm{~s}^{-1}$ for $\mathrm{ON} \mathrm{mBCs}$, $64 \pm 18 \mathrm{~ms} / \log$ quanta* $\mu \mathrm{m}^{-2 *} \mathrm{~s}^{-1}$ for cones and $38 \pm 5 \mathrm{~ms} / \log$ quanta* $\mu \mathrm{m}^{-2 *} \mathrm{~s}^{-1}$ for roddriven horizontal cells. Since both rod-driven horizontal cells and cones became faster at higher intensities, one can assume that part of this effect is a property of the photoreceptor response. The temporal gain of $\mathrm{ON} \mathrm{mBCs}$ did not differ from that of cones, while it was 
higher than that of rod-driven HCs. Note however, that cones are only active at intensities in which $\mathrm{ON}$ mBCs are reaching saturation (non-shaded area in Fig. 5D and Fig. 6D). Conversely, at the intensity range in which cone and $\mathrm{ON} \mathrm{mBC}$ responses overlap, $\mathrm{ON}$ mBCs are faster than cones (Fig. 5D). These findings again suggest that at least part of the $\mathrm{ON} \mathrm{mBC}$ early response kinetics derive from their intrinsic properties and not primarily from their pre-synaptic inputs.

An indication of the mechanism generating the transientness of the $\mathrm{ON} \mathrm{mBC}$ response came from the $I V$ relations of the light responses. Differently than expected based on literature (Berntson et al., 2004), light responses of goldfish ON mBCs did not reverse at $0 \mathrm{mV}$ (Fig. 6A, $n=81$ ). Instead, the $I V$ relation of the light responses was inwardly rectifying, and the light response kinetics changed in a voltage dependent manner: they became more transient at positive potentials (Fig. 6B). Fig. 6C summarizes the results obtained in $8 \mathrm{ON} \mathrm{mBCs}$. Responses at positive potentials are significantly smaller $\left(\mathrm{P}=5.91 * 10^{-6}\right)$ and more transient $\left(\mathrm{P}=4.69 * 10^{-6}\right)$, as indicated by the charge transfer and full width at half-maximal response (FWHM), respectively.

Because the pharmacology of these rod-driven responses is consistent with a single non-specific conductance and because cones are not responsive to the stimulus intensities used in these experiments (Fig. 6D), the lack of a clear reversal of the ON $\mathrm{mBC}$ light response is most likely due to poor space clamp of the dendrites (Spruston et al., 1993). Such space clamp problem could be caused by the activation of voltage-gated channels during depolarization, or due to gap-junctional coupling. We therefore studied first the effect of voltage-gated currents. The light-induced $I V$ relations in $\mathrm{ON}$ mBCs (Fig. 6E, grey symbols) deviate from linearity at the same potential range in which outwardly rectifying channels are active (Fig. 6E, black symbols). We next set out to investigate whether these channels generate the intensity-dependent transientness of ON $\mathrm{mBC}$ light responses.

\section{$K^{+}$Channel Block Prevents Gain Control of Rod-Driven Light Responses}

This outwardly rectifying voltage-gated current in bipolar cells has already been characterized as a delayed-rectifier, carried by $\mathrm{K}^{+}$ions (Kaneko and Tachibana, 1985; Klumpp et al., 1995; Lasater, 1988; Tessier-Lavigne et al., 1988). To determine whether this kind of channel is essential for the kinetic changes in $\mathrm{ON} \mathrm{mBC}$ responses, we blocked $\mathrm{K}^{+}$channels by bath-applying the blocker tetraethylammonium (TEA, 10-50 mM). The choice of external block was made because use of $\mathrm{Cs}^{+}$and TEA in the patch pipette failed to abolish the results shown so far, probably due to the fact that $\mathrm{ON} \mathrm{mBCs} \mathrm{are} \mathrm{electrically}$ coupled (Arai et al., 2010) - signals recorded from one cell are contributed by the coupled network. 

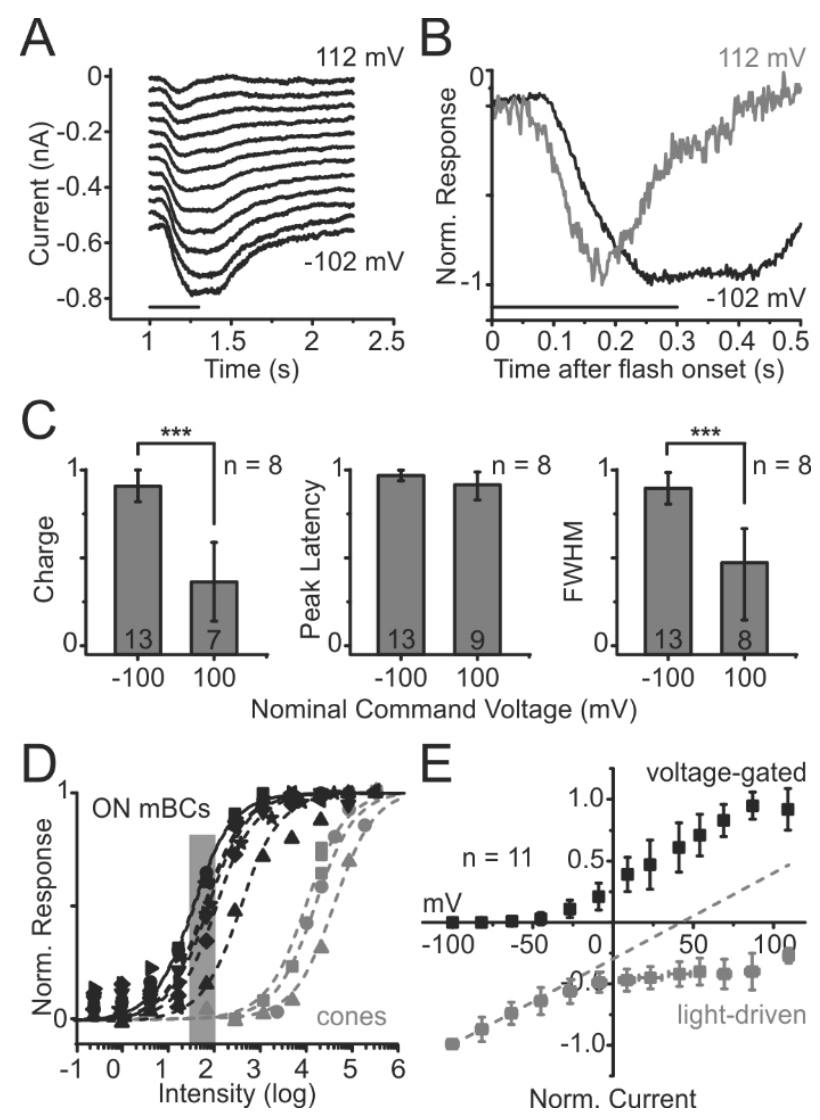

Figure 6. A voltage-gated $\mathrm{K}^{+}$current interferes with the light-driven conductance.

A) Unexpected absence of reversal for the light-driven conductance. Light-driven current responses of an axotomized $\mathrm{ON} \mathrm{mBC}$ clamped at different potentials from a $V_{\text {hold }}$ of $-64 \mathrm{mV}$ (from bottom to top trace: $-102,-83,-63,-44,-25,-5,14,34,53,73,92,112 \mathrm{mV})$. Stimulus was a $1.83 \log$ full-field flash at $550 \mathrm{~nm}$. Light stimulus timing depicted in the figure.

B) Potential-dependent kinetic changes of the light-driven current. The responses to $-102 \mathrm{mV}$ and $112 \mathrm{mV}$ in (A) were normalized and depicted in a faster time scale to show that the light response is more transient at positive potentials.

C) Summary of results obtained in $8 \mathrm{ON}$ mBCs subjected to the protocol in (A). Current traces for nominal voltage steps to $-100 \mathrm{mV}$ and $+100 \mathrm{mV}$ from a nominal holding potential $\left(V_{\text {hold }}\right)$ of $60 \mathrm{mV}$ (values not corrected for junction potential or series resistance, since these vary from cell to cell) were integrated to calculate the mean charge transfer \pm SD (left panel), mean time-topeak or peak latency $\pm \mathrm{SD}$ (middle panel) and mean full width at half maximum $\pm \mathrm{SD}$ (FWHM, right panel). The numbers inside each column in the graphs are the number of records used for each nominal command voltage.

D) Absence of reversal potential for the light-driven conductance is not due to cone influence. Normalized intensity-response relations of the $8 \mathrm{ON} \mathrm{mBCs}$ in $(\mathrm{C})$ and 3 cones (two M-cones and one L-cone) for full-field stimulation at $550 \mathrm{~nm}$ (black and grey symbols, respectively). Responses measured at the peak; dashed lines are Hill fits to the data. For most part of the dynamic range of $\mathrm{ON} \mathrm{mBCs,} \mathrm{cones} \mathrm{are} \mathrm{still} \mathrm{not} \mathrm{active} \mathrm{and} \mathrm{cannot} \mathrm{therefore} \mathrm{account} \mathrm{for} \mathrm{the}$ potential-dependent rectification and change in kinetics shown here. The shaded area highlights the stimulus intensities used in (A), (B) and (C).

E) Rectification of light-driven $I V$ relations in $\mathrm{ON} \mathrm{mBCs}$ coincides with the activation of voltagegated $\mathrm{K}^{+}$currents. Mean normalized light-induced current (grey symbols) and mean normalized voltage-gated current (black symbols) of 11 axotomized ON mBCs ( 26 records). Light responses measured at the peak; voltage-gated currents calculated by subtracting the dark $I V$ s from linear regressions extrapolated from data points more negative than the holding membrane potential ( $\left.V_{\text {hold }}\right)$. The dashed line shows that the light-induced slope conductance changes at around the same potential in which an outwardly rectifying voltage-gated current is activated. 
Fig. 7A-B shows that $\mathrm{ON} \mathrm{mBC}$ light responses were larger and less transient when $\mathrm{K}^{+}$channels were blocked (grey traces) compared to control (black traces). To quantify the effect of blocking $\mathrm{K}^{+}$channels on the light responses, we integrated the light responses and obtained their area, peak latency and FWHM and compared the mean of three values pre-TEA and during TEA wash-in (Fig. 7C). Fig. 7D shows that in all cases, TEA increased the response amplitudes $\left(>\right.$ area, $\mathrm{P}=2.55^{*} 10^{-9}$ ), slowed down responses ( $<$ peak latency, $\mathrm{P}=2.65^{*} 10^{-11}$ ) and decreased transientness ( $>\mathrm{FWHM}, \mathrm{P}=2.94 * 10^{-7}$ ). The resting membrane potential ( $\left.V_{\text {rest }}\right)$ of $\mathrm{ON} \mathrm{mBCs} \mathrm{did} \mathrm{not} \mathrm{significantly} \mathrm{change} \mathrm{during} \mathrm{TEA}$ application (Fig. 7E). Although one would expect TEA to tonically depolarize ON mBCs, TEA also blocks $\mathrm{K}^{+}$channels in photoreceptors (Bader et al., 1982; Fan and Yazulla, 1997), depolarizing them and thus leading to an increased basal glutamate release, which would in turn hyperpolarize $\mathrm{ON} \mathrm{mBCs}$. Together, TEA pre- and postsynaptic effects could lead to no net change in $\mathrm{ON} \mathrm{mBC}$ resting membrane potential (Fig. 7E). The peak/plateau ratio increased significantly, indicating that the response became less transient (Fig. 7F). These results suggest that $\mathrm{K}^{+}$channels are responsible for the transientness observed in rod-driven $\mathrm{ON} \mathrm{mBC}$ light responses.

\section{Voltage-Gated $\mathrm{K}^{+}$Channels Are Concentrated in Distal Dendritic Compartments}

The data so far suggest an intriguing interaction between the rod-driven glutamate-gated channels and $\mathrm{K}^{+}$channels. To get a better understanding of the subcellular compartmentalization of these voltage-gated conductances and their possible interactions with the glutamatergic channels, we generated a model $\mathrm{ON} \mathrm{mBC}$. The influence of the physical localization of $I_{\mathrm{KV}}$ on the rod-driven $I V$ relations of $\mathrm{ON} \mathrm{mBCs}$ was investigated by means of five simulated conditions: (i) $\mathrm{K}^{+}$channels localized only at the soma (Fig. 8A), (ii) $\mathrm{K}^{+}$channels localized exclusively at the primary dendrites (Fig. 8B), (iii) $\mathrm{K}^{+}$channels confined to the secondary dendrites (Fig. 8C), (iv) $\mathrm{K}^{+}$channels localized only at the dendritic shafts (Fig. 8D), and (v) $\mathrm{K}^{+}$channels localized exclusively at the tips of the secondary dendrites (Fig. 8E).

We then studied the relationship between the location and density of $I_{\mathrm{KV}}$, the nonlinearity of the whole-cell $I V$ relation and the rectification of the light response. When $I_{\mathrm{KV}}$ was located exclusively at the soma (Fig. 8A) or on the primary dendrites (Fig. 8B), voltage-gated currents (left panels) were always larger than those recorded in real cells (grey areas, $n=12$ ). The $I V$ relations of the light-driven conductance (right panels) were rather independent of $I_{\mathrm{KV}}$ when these channels were located in the soma or primary dendrites. Rectification was only present within the physiological range of voltage-gated $I V$ relations when $\mathrm{K}^{+}$channels were localized to more distal compartments such as the secondary dendrites (Fig. 8C), dendritic shafts (Fig. 8D) or to the tips of the dendrites (Fig. 8E). The largest rectification was observed when $I_{\mathrm{KV}}$ was confined to the tips of the 
dendrites (Fig. 8E), suggesting that a large part of these voltage-gated channels must be in close apposition to the sites of synaptic input.
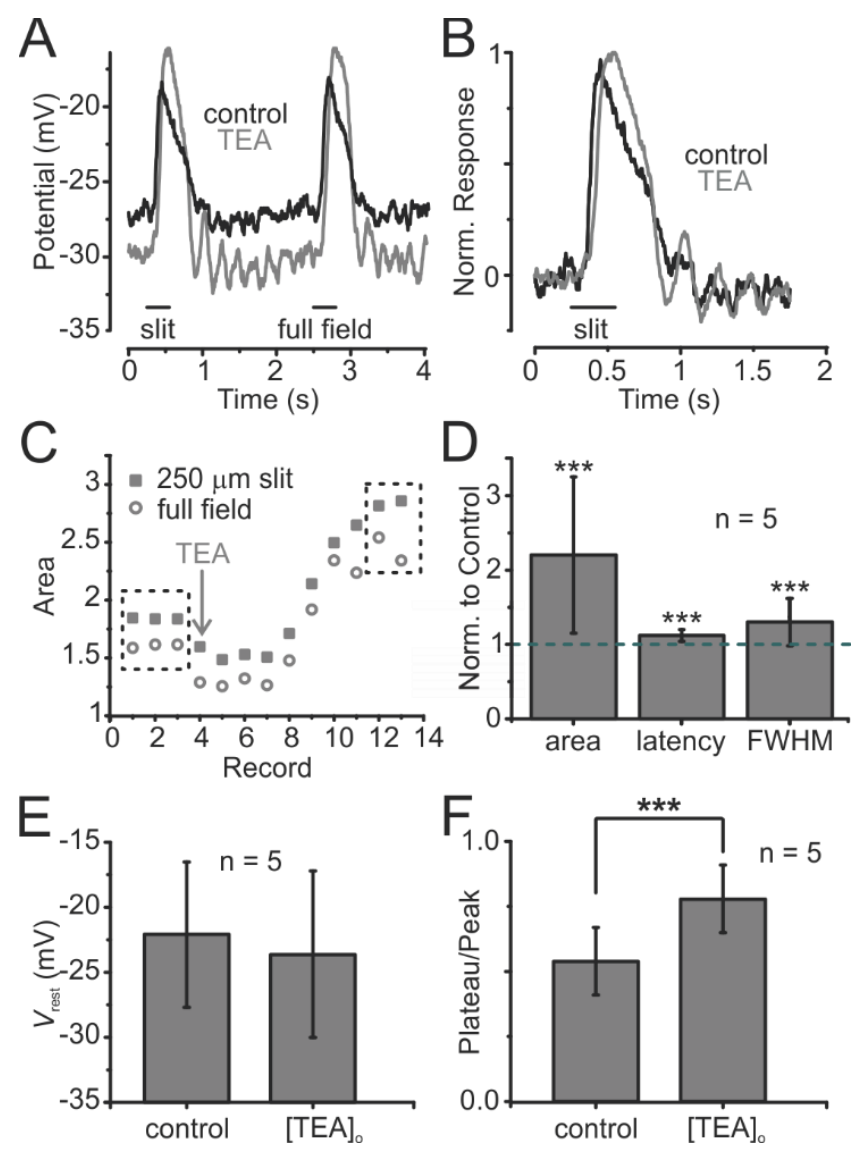

Figure 7. Voltage-gated $\mathrm{K}^{+}$currents speed up $\mathrm{ON} \mathrm{mBC}$ light responses.

A) Responses of an $\mathrm{ON} \mathrm{mBC}$ to two 250-ms light flashes at $550 \mathrm{~nm}$ (left: $250 \mu \mathrm{m}$ slit, $2.58 \mathrm{log}$; right: full-field, $1.59 \log$ ) in control Ringer's containing $250 \mu \mathrm{M}$ PTX and $5 \mu \mathrm{M}$ STRY to block GABAergic and glycinergic inputs (black trace) and in PTX+STRY+10 mM TEA to additionally block voltage-gated $\mathrm{K}^{+}$currents (grey trace). Responses in TEA are larger, broader, and slower, suggesting that $\mathrm{K}^{+}$currents make them faster and more transient, with little effect on resting membrane potential ( $\left.V_{\text {rest }}\right)$.

B) Traces in (A) for stimulation with a slit are normalized and shown on a shorter time scale to emphasize that responses are slower and less transient in TEA.

C) To quantify the effects of TEA, ON mBC responses before and during bath application of the drug were integrated and the area, peak latency and FWHM of the integrated responses were compared between the mean of three pre-TEA records and the mean of the last two records in TEA (dashed boxes) to determine how these parameters changed during wash in.

D) Summary of results obtained in 5 cells normalized to pre-TEA values. Graphs show means \pm SDs.

E) Change in $V_{\text {rest }}$ during the experiment was negligible in the same 5 neurons as in (D).

F) Voltage-gated $\mathrm{K}^{+}$channels make $\mathrm{ON} \mathrm{mBC}$ light responses more transient. In external TEA, the relationship between response amplitudes measured at the plateaus $(350-550 \mathrm{~ms}$ after light onset) and at the early peaks is significantly changed $\left(\mathrm{P}=8.21 * 10^{-4}\right)$ : plateaus are about two times smaller in control (plateau/peak ratio $=0.54 \pm 13$ in control versus $0.78 \pm 0.13$, mean \pm $\mathrm{SD})$ and cells are more transient before TEA application. 
VOLTAGE-GATED CURRENTS LIGHT-DRIVEN CURRENTS

A

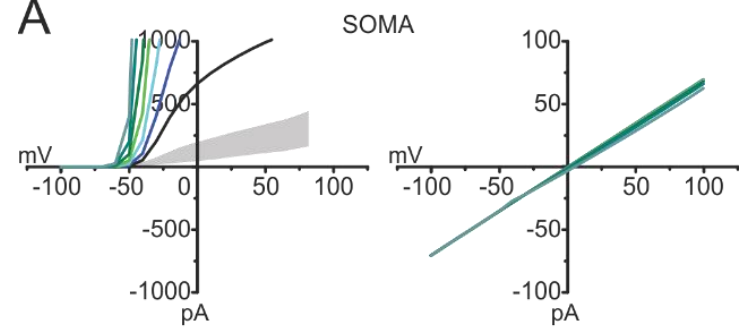

B

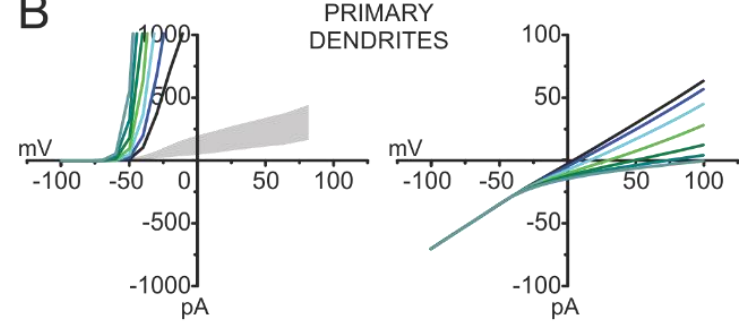

C SECONDARY
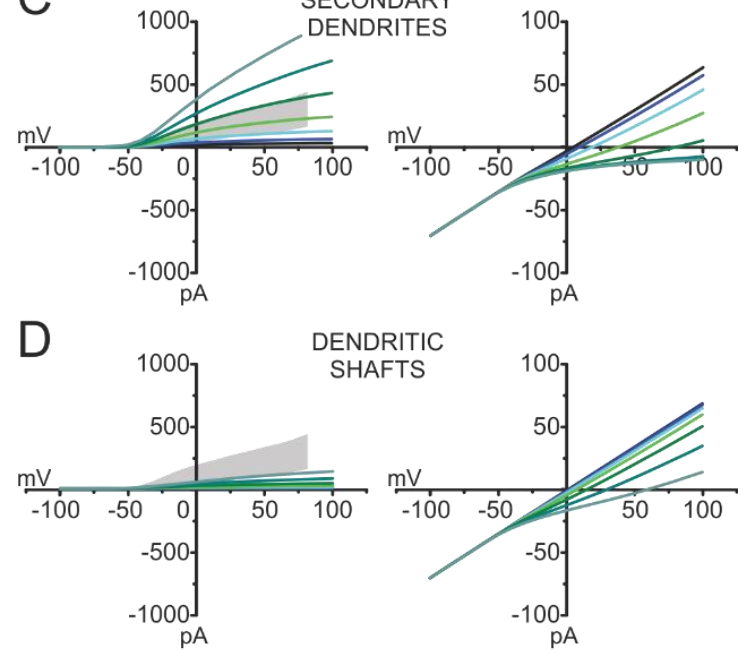

$\mathrm{E}$

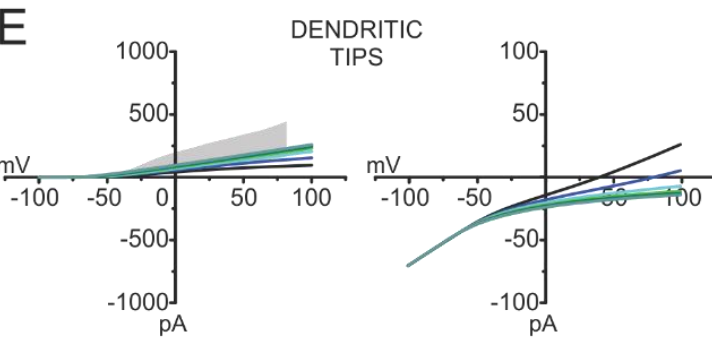

$\begin{array}{lll}-25 \mathrm{pS} / \mu \mathrm{m}^{2} & -100 \mathrm{pS} / \mu \mathrm{m}^{2}-400 \mathrm{pS} / \mu \mathrm{m}^{2} \\ -50 \mathrm{pS} / \mu \mathrm{m}^{2}-200 \mathrm{pS} / \mu \mathrm{m}^{2}-800 \mathrm{pS} / \mu \mathrm{m}^{2}-1600 \mathrm{pS} / \mu \mathrm{m}^{2}\end{array}$
Figure 8. ON mBC voltage-gated $\mathrm{K}^{+}$channels are concentrated in distal dendritic compartments.

The graphs show the magnitude of voltage-gated currents (left) and their effect on the lightinduced $I V \mathrm{~s}$ (right) of a model ON mBC when $I_{\mathrm{KV}}$ is placed in different cell compartments.

A) Soma.

B) Primary dendrites.

C) Secondary dendrites.

D) Dendritic shafts.

E) Dendritic tips.

For all panels, $I_{\mathrm{KV}}$ conductance values are depicted at the bottom of the figure. Grey area represents mean $\pm \mathrm{SD}$ voltage-gated currents of 28 records in 12 cells. For these simulations, the diameter of the secondary dendrites and dendritic shafts was set to $0.01 \mu \mathrm{m}$.

\section{Dendritic Voltage-Gated $K^{+}$Channels Change the Kinetics of Rod-Driven Responses}

We next investigated the effects of inserting $I_{\mathrm{KV}}$ at the dendritic tips on the kinetics of the rod-driven responses in current clamp and voltage-clamp modes. First, we gradually increased the polarization of the model rods, in order to simulate an intensity-response relation in the $\mathrm{ON} \mathrm{mBC}$ in the absence and presence of a small $\mathrm{K}^{+}$channel conductance at the dendritic tips $\left(25 \mathrm{pS} / \mu \mathrm{m}^{2}\right)$. In these simulations, dendritic $I_{\mathrm{KV}}$ increased the gain of the rod-ON mBC synapse (Fig. 9A): rod-driven $\mathrm{ON} \mathrm{mBC}$ responses recorded at the soma became larger (grey traces) than when there was no $I_{\mathrm{KV}}$ (black traces), because of the $I_{\mathrm{KV}}-$ 
induced change in $V_{\text {rest }}$ (arrow) that increased the driving force for the rod-driven conductance.

This result might seemingly differ from the one presented in Fig. 7A-B, which show no net change in $V_{\text {rest }}$ and an increase in $\mathrm{ON} \mathrm{mBC}$ response amplitudes upon $\mathrm{K}^{+}$ channel block. However, one needs to take into consideration the fact that bath application of TEA has both pre- and post-synaptic effects, as explained previously, while our model includes only mechanisms intrinsic to the model bipolar cell. If the $\mathrm{K}^{+}$channels are (partially) blocked intracellularly, $\mathrm{ON} \mathrm{mBCs}$ indeed depolarize: cells recorded with $\mathrm{Cs}^{+}{ }_{-}$ and/or TEA-based pipette solutions were about $20 \mathrm{mV}$ more depolarized than those recorded with $\mathrm{K}^{+}$-based solutions $\left(-26 \pm 16 \mathrm{mV}\right.$ vs. $-45 \pm 16 \mathrm{mV}$, respectively, $n_{1}=8, n_{2}=$ $13, \mathrm{P}=0.0168)$. Therefore, one expects that the presence of $\mathrm{K}^{+}$channels in $\mathrm{ON} \mathrm{mBCs}$ leads to hyperpolarization of these cells (Fig. 9A), with a consequent increase in the driving force for their glutamate-driven responses. Fig. 9B depicts the normalized minimal and maximal responses of the model cell for the grey traces in Fig. 9A, to illustrate that this small voltage-gated conductance density at the dendritic tips already speeds up rod-driven responses as the rod hyperpolarization increases.

We subsequently varied the dendritic $I_{\mathrm{KV}}$ conductance density to further investigate the effect of dendritic $I_{\mathrm{KV}}$ in the response kinetics of $\mathrm{ON} \mathrm{mBCs}$. Fig. 9C shows that increasing $I_{\mathrm{KV}}$ density at the dendritic tips indeed leads to hyperpolarization of the cell membrane. Furthermore, the response kinetics of the model $\mathrm{ON} \mathrm{mBC}$ depended on $I_{\mathrm{KV}}$ density because time-to-peak for maximal rod hyperpolarization decreased as one increased the voltage-gated conductance density (Fig. 9D). These kinetic changes in current-clamp are summarized in Fig. 9E, which shows the effects of $I_{\mathrm{KV}}$ on response amplitude (area), speed (peak latency) and transientness (FWHM). Increasing dendritic $I_{\mathrm{KV}}$ density makes $\mathrm{ON} \mathrm{mBC}$ light responses smaller (< area) and faster $(<$ peak latency and FWHM).

We also tested whether this model could reproduce the voltage-dependent kinetic changes observed in voltage-clamp (Fig. 6). The potential at the dendritic tips $\left(V_{\text {tip }}\right)$ of the model $\mathrm{ON} \mathrm{mBC}$ was investigated by applying a somatic voltage step from -60 to $+100 \mathrm{mV}$ and increasing the dendritic $I_{\mathrm{KV}}$ density (Fig. 9F). As expected, $I_{\mathrm{KV}}$ worsened the space clamp of the distal dendritic compartment. Finally, we simulated an experiment similar to that of Fig. 6A-B (Fig. 9G-H) and observed that this $I_{\mathrm{KV}}$-induced loss of space clamp indeed prevents the rod-driven responses of the model $\mathrm{ON} \mathrm{mBC}$ from reversing at $0 \mathrm{mV}$, because the dendritic tips do not reach $0 \mathrm{mV}$. Furthermore, the responses of the model at more depolarized levels are more transient than the ones to hyperpolarizing steps (Fig. 9H), resembling our physiological observations. To summarize, our findings suggest that $\mathrm{K}^{+}$channels are concentrated at the dendritic tips of $\mathrm{ON} \mathrm{mBCs}$ and actively regulate the gain and speed of synaptic transmission from rods onto these neurons, by 
accelerating the time-to-peak of $\mathrm{ON} \mathrm{mBC}$ light responses and their subsequent repolarization in an intensity-dependent manner.
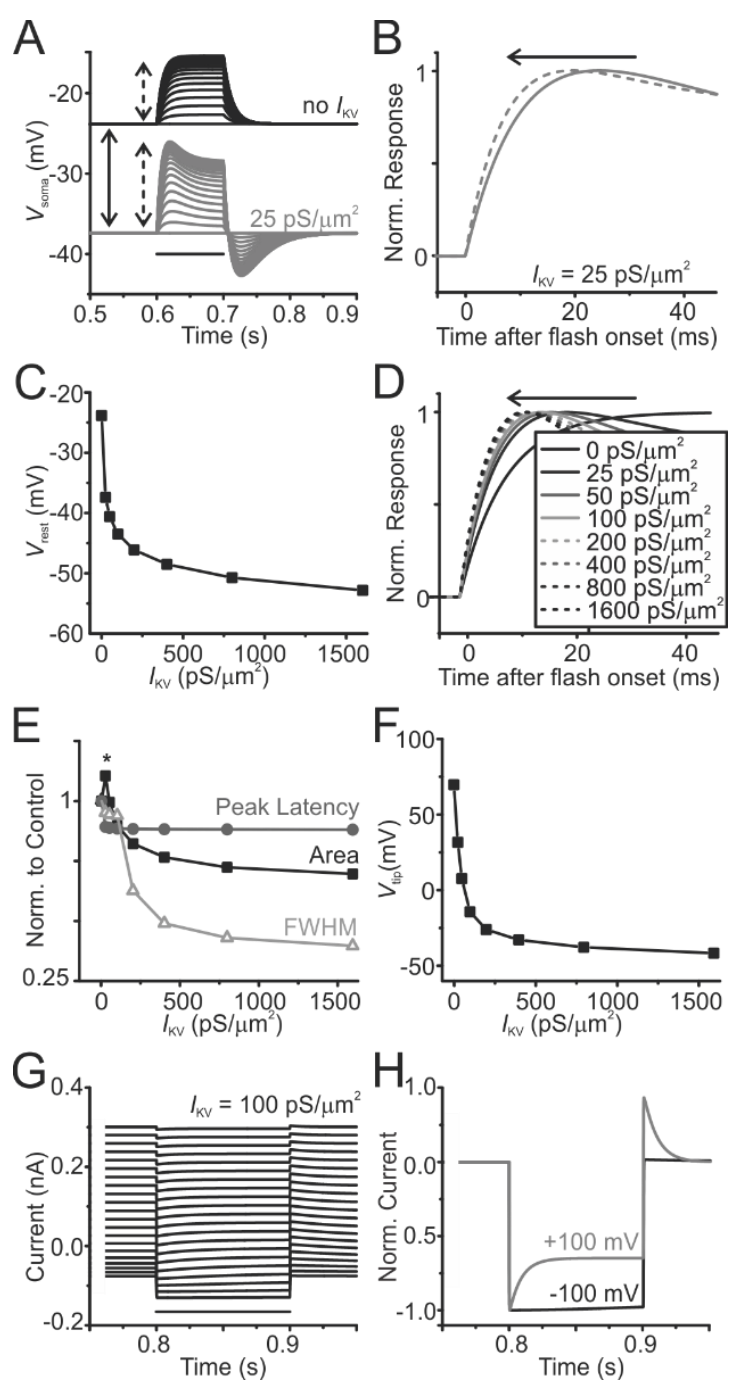

Figure 9. Dendritic IKv changes the kinetics of $\mathrm{ON} \mathrm{mBC}$ light responses.

A) Somatic voltage responses ( $\left.V_{\text {soma }}\right)$ of the model ON mBC to a series of hyperpolarizing steps of the model rods when the cell lacks voltage-gated $\mathrm{K}^{+}$channels (black traces) and with a $25 \mathrm{pS} / \mu \mathrm{m}^{2}$ voltage-gated $\mathrm{K}^{+}$conductance inserted at the tips of the dendrites (grey traces). $I_{\mathrm{KV}}$ hyperpolarizes the model $\mathrm{ON} \mathrm{mBC}$ (solid arrow) and makes light responses larger than when there is no $I_{\mathrm{KV}}$ (dashed arrows).

B) Depolarization-induced activation of $I_{\mathrm{KV}}$ speeds up $\mathrm{ON} \mathrm{mBC}$ responses. Normalized somatic voltage responses of the model $\mathrm{ON} \mathrm{mBC}$ to the smallest and largest hyperpolarizing steps of the model rods shown in (A), with $I_{\mathrm{KV}}$ at the dendritic tips (conductance density depicted in the figure). Responses become faster as the light-driven depolarization increases (arrow).

C) $V_{\text {rest }}$ hyperpolarizes with increasing dendritic $I_{\mathrm{KV}}$ conductance density.

D) $\mathrm{ON} \mathrm{mBC}$ response kinetics depend on $I_{\mathrm{KV}}$ density. Normalized somatic voltage responses of the model $\mathrm{ON} \mathrm{mBC}$ to maximal hyperpolarization of the model rods, with increasing $I_{\mathrm{KV}}$ densities at the $\mathrm{ON} \mathrm{mBC}$ dendritic tips (values in $\mathrm{pS} / \mu \mathrm{m}^{2}$ depicted in figure).

E) Changes in $\mathrm{ON} \mathrm{mBC}$ response kinetics with increasing $I_{\mathrm{KV}}$ densities. Responses of the model ON $\mathrm{mBC}$ to maximal hyperpolarization of the model rods were integrated to investigate changes in response area (= amplitude), breadth (=FWHM) and speed (peak latency) elicited by changes in 
$I_{\mathrm{KV}}$ density at the dendritic tips in relation to control responses (no $I_{\mathrm{KV}}$ ). The asterisk denotes an initial increase in response amplitude due to the change in $V_{\text {rest }}$.

F) Dendritic $I_{\mathrm{KV}}$ prevents proper space clamp of remote compartments. Potential measured at the dendritic tip ( $\left.V_{\text {tip }}\right)$ of the model $\mathrm{ON} \mathrm{mBC}$ during a somatic voltage step to $+100 \mathrm{mV}$.

G) $I_{\mathrm{KV}}$ is responsible for kinetic changes in light responses measured in voltage-clamp mode. Voltage-clamp experiment similar to the one in Fig. 6A. The model ON mBC was clamped from $-60 \mathrm{mV}$ to a series of voltage steps from -100 to $+100 \mathrm{mV}$ and stimulated with light (= hyperpolarization of the model rod) during the protocol. "Light" stimulus timing depicted as a horizontal bar in the picture. Similar to what happens in real cells, light responses do not reverse due to loss of space clamp and become more transient at positive potentials. $I_{\mathrm{KV}}$ conductance density depicted in the figure.

H) Potential-dependent kinetic changes of the rod-driven current. The responses to $-100 \mathrm{mV}$ and $100 \mathrm{mV}$ in $(\mathrm{G})$ were normalized and depicted in a faster time scale to show that the light response of the model $\mathrm{ON} \mathrm{mBC}$ is more transient at positive potentials. For these simulations, the diameter of the secondary dendrites and dendritic shafts was $0.01 \mu \mathrm{m}$.

\section{Electrical Coupling Increases Rectification}

Since real ON mBCs are electrically coupled (Arai et al., 2010), and electrical coupling is known to induce space clamp problems such as the one reported here (Pang et al., 2004; Trexler et al., 2005), we proceeded to investigate the influence of electrical coupling in the light-induced currents of $\mathrm{ON}$ mBCs (see Materials and Methods and Fig. 2B). The single gap junctional range of conductances $\left(g_{\text {gap }}\right)$ used in the model are summarized in Fig. 10A, as well as the corresponding input resistance $\left(R_{\text {in }}\right)$ of the central cell for each $g_{\text {gap. These }} g_{\text {gap }}$ values were chosen such as to yield a receptive field diameter of approximately $370 \mu \mathrm{m}$, which is close to the lower values reported in literature for carp ON mBCs (from $300 \mu \mathrm{m}$ to $1 \mathrm{~mm}$; Saito and Kujiraoka, 1988), and for salamander ON BCs (from 345 to $662 \mu \mathrm{m}$; Borges and Wilson, 1987).

The spatial integration in the ON mBC network is illustrated in Fig. 10B, in which the somatic membrane potential ( $V_{\text {soma }}$ ) of cells in the different rings of the ON mBC lattice are depicted for a voltage step $\left(V_{\text {step }}\right)$ of $100 \mathrm{mV}$ applied to the soma of the central cell. Neighboring cells are polarized to a smaller extent by the $V_{\text {step }}$, and the amount of polarization is proportional to $g_{\text {gap. }}$. Consequently, as shown in Fig. 10C, electrical coupling leads to an increase in the amplitude of the $\mathrm{ON} \mathrm{mBC}$ whole-cell currents. The reversal potential of all whole-cell currents is around $-40 \mathrm{mV}$, because this is the resting membrane potential of the cells in the $\mathrm{ON} \mathrm{mBC}$ network. When the recorded $\mathrm{ON} \mathrm{mBC}$ is clamped at this potential, no current will flow through the gap junctions. This means that currents originating from photoreceptor inputs to the central cell will also be shared by the coupled lattice, and the amount of current escape will depend on $g_{\text {gap }}$.

Fig. 10D shows that electrical coupling shifts the reversal potential ( $\left.V_{\text {rev }}\right)$ of the light-induced $I V$ relation to more positive potentials, due to the fact that the neighboring cells are not clamped to the same extent as the central $\mathrm{ON} \mathrm{mBC}$. The slope of the lightinduced $I V$ relations becomes steeper as the strength of coupling augments. This happens because the total rod-driven $I V$ relation measured in the central $\mathrm{ON} \mathrm{mBC}$ is the sum of 
the $I V$ relations of the central neuron and the relations originating from neighboring cells, which are smaller and slightly shifted in the voltage axis. However, in the absence of $I_{\mathrm{KV}}$, there is no rectification of the rod-driven current.
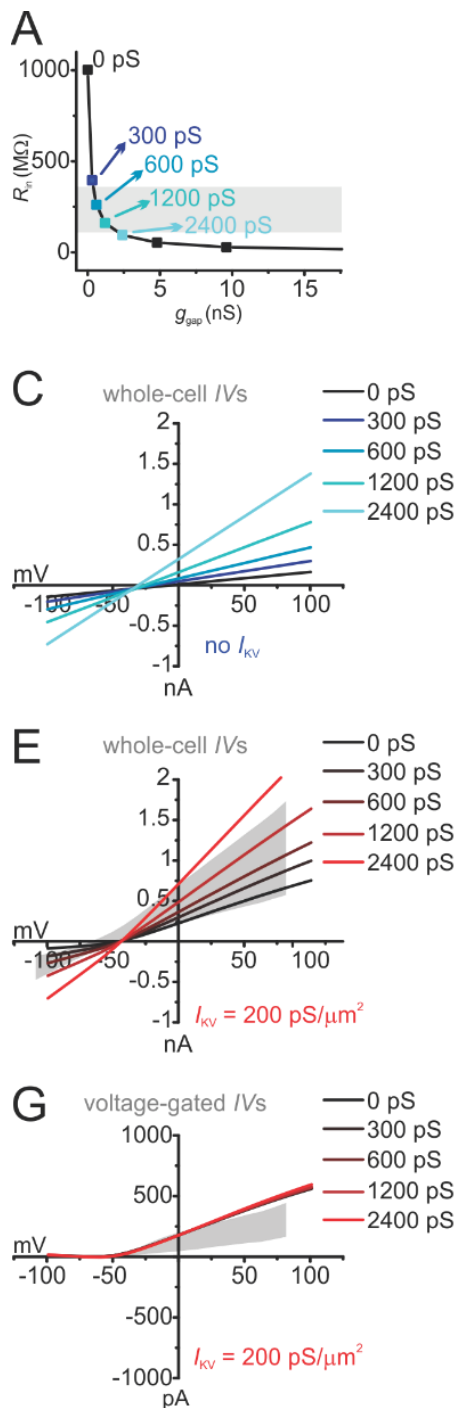
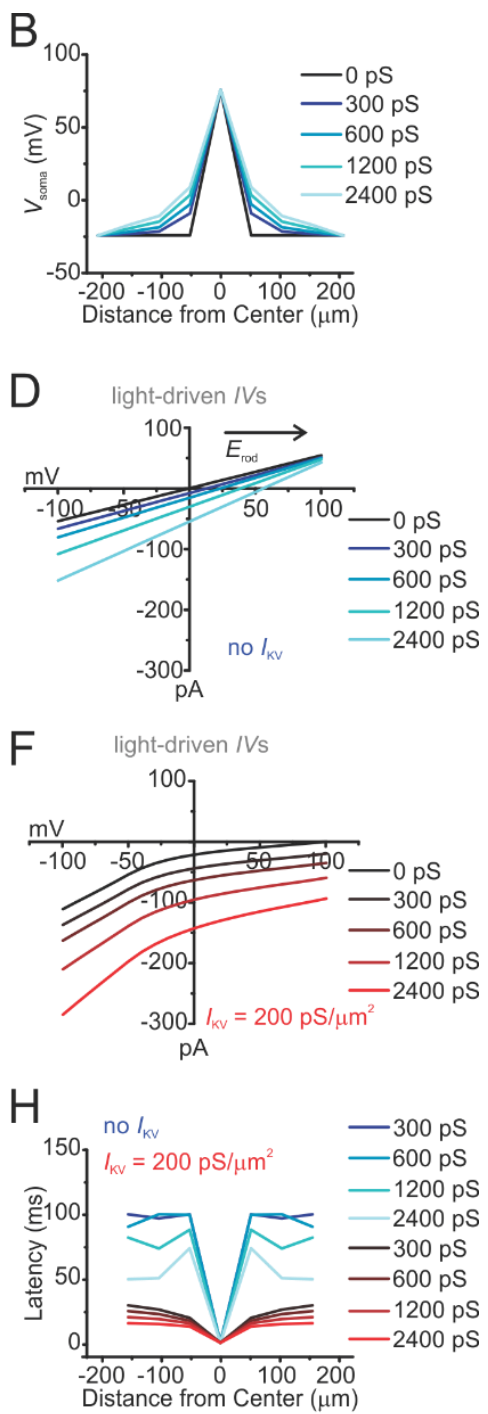

Figure 10. The influence of electrical coupling on the physiology of $\mathrm{ON}$ mBCs.

A) Changes in input resistance $\left(R_{\text {in }}\right)$ with increased gap junctional coupling. The grey area shows mean $\pm \mathrm{SD} R_{\text {in }}$ measured in 30 records from 8 axotomized ON mBCs.

B) Electrical coupling increases the size of the $\mathrm{ON} \mathrm{mBC}$ receptive field. Somatic membrane potentials of cells in different rings of the coupled syncytium during a $+100 \mathrm{mV}$ voltage step applied to the central $\mathrm{ON} \mathrm{mBC}$ from $V_{\text {rest }}\left(-24 \mathrm{mV}\right.$, due to the absence of $\mathrm{K}^{+}$conductances in this simulation). The amount of polarization of the neighboring cells increases with the strength of coupling (values of $g_{\text {gap }}$ are depicted in the legend).

C) Electrical coupling increases whole-cell currents. Whole-cell $I V$ relations of the central $\mathrm{ON} \mathrm{mBC}$ when clamped at a $V_{\text {hold }}$ of $-70 \mathrm{mV}$ and stepped from -100 to $+100 \mathrm{mV}$ for different strengths of coupling (values of $g_{\text {gap }}$ are depicted at the right corner of this row). As the strength of coupling increases, $R_{\text {in }}$ decreases and as a result whole-cell currents are augmented.

D) Electrical coupling shifts the apparent reversal potential for the rod-driven currents $\left(E_{\text {rod }}\right)$. Lightinduced $I V$ curves measured in the central $\mathrm{ON} \mathrm{mBC}$ for the simulation in (C). $E_{\mathrm{rod}}$ shifts proportionally towards more positive values as coupling is increased, but no rectification is induced. 
E-G) Same simulations as in (C-D), but with $I_{\mathrm{Kv}}$ at the dendritic tips $\left(200 \mathrm{pS} / \mu \mathrm{m}^{2}\right)$. For these simulations, diameter of secondary dendrites $=0.02 \mu \mathrm{m}$, and diameter of the dendritic shafts $=$ $0.01 \mu \mathrm{m}$. Values of $\mathrm{g}_{\text {gap }}$ are depicted in the legend. Grey area represents mean $\pm \mathrm{SD}$ of 28 records in 12 cells.

F) Electrical coupling increases the rectification induced by $I_{\mathrm{KV}}$. Simulations of the changes in the rod-driven $I V$ relation of an $\mathrm{ON} \mathrm{mBC}$ for full-field stimulation induced by varying the gap junctional conductance when $\mathrm{K}^{+}$channels are placed at the dendritic tips.

G) Voltage-gated $I V$ relations for the simulation in (E). Grey area represents mean \pm SD of 28 records in 12 cells.

H) $I_{\mathrm{KV}}$ counteracts the slowing down in response kinetics caused by electrical coupling. Peak latency of light responses of $\mathrm{ON} \mathrm{mBCs}$ in the coupled network for the simulation in (B) without dendritic $I_{\mathrm{KV}}$ (blue traces) and with $I_{\mathrm{KV}}$ at the dendritic tips (red traces). $\mathrm{G}_{\mathrm{gap}}$ values depicted in the figure.

When $\mathrm{K}^{+}$channels are placed at the tips of the dendrites of all cells in the coupled syncytium (Fig. 10E-G), the activation of these channels in both the central ON mBC and in the coupled network enlarges the voltage difference between the somatic compartments of the central cell and its neighbors. In this condition, the effects of coupling will become asymmetrical: at more depolarized potentials, the activation of $I_{\mathrm{KV}}$ in the neighboring cells will lead to an increase in the rectification of the rod-driven $I V$ relation (Fig. 10F). Here, too, the slope of the total light-induced $I V$ relations changes with the strength of coupling, because it results from the sum of many $I V$ relations slightly displaced in the voltage axis. Inward currents increase more at negative potentials relative to those at positive potentials because the activation of dendritic $\mathrm{K}^{+}$channels in both the central and neighboring cells increases space clamp problems at depolarized levels. These curves strongly resemble the $I V$ relations of Fig. $\mathbf{6 E}$; the whole-cell $I V$ s and leaksubtracted $I V$ s for the same simulations are presented in Fig. 10E and $\mathbf{G}$, respectively, as well as the range of $I V$ s recorded from real cells (grey areas represent mean \pm SD of 28 records from 12 cells). Taken together, these simulations suggest that although electrical coupling between mixed-input $\mathrm{ON}$ mBCs does not induce rectification of light-driven conductances per se, it does increase the effects of dendritic $\mathrm{K}^{+}$channels on rod-driven $I V$ relations.

Because electrical coupling slows down cells due to the increase in capacitive load, we measured the response peak latency in the coupled network with and without dendritic $\mathrm{K}^{+}$channels (Fig. 10H) to a $100 \mathrm{mV}$ voltage step applied to the central ON mBC of the lattice (spread of potential for the same experiment is depicted in Fig. 10B). Similar to what happens in isolated cells (Fig. 9A and D), adding a voltage-gated conductance to the dendritic tips of $\mathrm{ON} \mathrm{mBCs} \mathrm{(red} \mathrm{traces)} \mathrm{speeds} \mathrm{up} \mathrm{responses} \mathrm{of} \mathrm{the} \mathrm{coupled} \mathrm{cells}$ considerably, and decreases the latency differences between the $\mathrm{g}_{\mathrm{gap}}$ values used. Since the gap junctional conductance of these neurons changes by up to two fold with light adaptation (Arai et al., 2010), dendritic $I_{\mathrm{KV}}$ could provide a way of keeping responses of the $\mathrm{ON} \mathrm{mBC}$ lattice equally fast, regardless of the adaptive state of the retina. 


\section{The Resistance of Distal Dendritic Compartments Must Be High}

For our model to reproduce the voltage-clamp experimental data (Fig. 6A-B and 9G-H), we needed to simulate a high resistance compartment between the soma and the dendritic tip. This was achieved by working with very fine secondary dendrites and shafts $(0.01-$ $0.02 \mu \mathrm{m}$ in diameter) - larger dendrites failed to yield the same results (not shown). Although a narrowing of the secondary dendrites in relation to the dendritic tips was described in ON mBCs of the smooth dogfish (Witkovsky and Stell, 1973), goldfish (Ishida et al., 1980; Klooster et al., 2001; Stell, 1978) and rudd (Scholes, 1975), as well as in rod BCs of the guinea pig and rabbit retinas (Ladman, 1958; Sjostrand, 1998a; Sjostrand, 1998b), it is unlikely that dendritic diameters are as small as in our simulations. Rather, one needs to consider the influence of the extracellular resistance of the rod pedicle onto this system.

Fig. 11A shows a schematic drawing of the circuit involved in the rectification of the light-driven conductance of $\mathrm{ON} \mathrm{mBCs}$. In this drawing, secondary dendrites and dendritic shafts were lumped into one resistor. The resistance of the secondary dendrites and shafts at rod spherules (2) and cone pedicles (2') is larger than that of the soma and primary dendrites (1). In a voltage-clamp experiment, current flowing from the soma (1) to the tips of the dendrites ( 3 and $3^{\prime}$ ) induces a voltage drop between the somatic compartment (as measured in the nodes $a$ and $a^{\prime}$ ) to the tips (measured in nodes $b$ and $\left.b^{\prime}\right)$. The residual voltage that reaches the tips opens the voltage-gated $\mathrm{K}^{+}$channels located at the tips, and voltage control of the dendritic tips is lost.

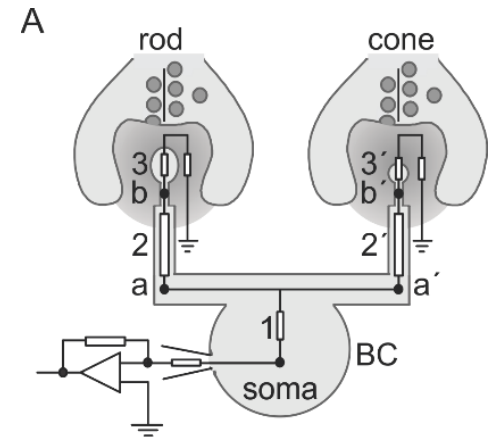

Figure 11. Electrical circuit involved in the rectification of light-induced $I V$ s.

A) Schematic drawing of the circuit involved in the rectification of the light-driven conductance of $\mathrm{ON} \mathrm{mBCs}$.

B) Simplified equivalent scheme of an ON mBC. $V_{\text {soma }}$, membrane potential at the soma; $V_{2}$, potential at the secondary dendrites; $V_{3}$, potential at the tips of the $\mathrm{ON} \mathrm{mBC}$ dendrites; $R_{\mathrm{m}}$, membrane resistance of the soma and the primary dendrites; $R_{\mathrm{in} 2}$, intracellular resistance of the dendrites invaginating rods; $R_{\mathrm{G}}$,

B

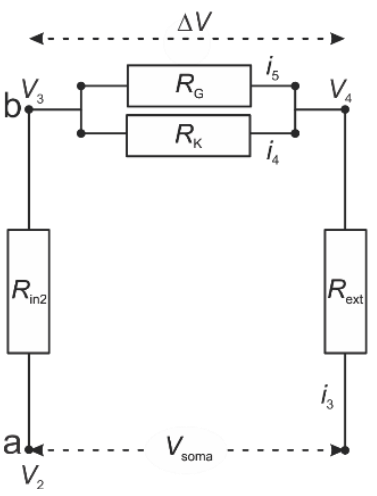
TRPM1 conductance; $R_{\mathrm{K}}$, dendritic $\mathrm{K}^{+}$conductance; $R_{\mathrm{ext}}$, resistance of the extracellular space; $i_{3}$, current flowing through $R_{\mathrm{G}}$ and $R_{\mathrm{K}}$ at the dendritic tips. For formulas and further explanation, please see text. 
Fig. 11B shows the simplified equivalent scheme of an $\mathrm{ON} \mathrm{mBC}$ dendrite contacting a rod in situ (the left half of Fig. 11A). There are two variable resistors in this dendrite: (a) $R_{\mathrm{K}}$, representing the voltage-gated $\mathrm{K}^{+}$conductance, and (b) $R_{\mathrm{G}}$, the glutamate-gated conductance through mGluR6/TRPM1. The total current flowing in the dendrite, $i_{1}$, will flow through $R_{\mathrm{in} 2}$, through the resistances at the dendritic tips $R_{\mathrm{G}}$ and $R_{\mathrm{K}}$, and through the extracellular compartment $\left(R_{\text {ext }}\right)$. With this scheme, one can calculate whether $R_{\text {in2 }}$ is determinant for the membrane voltage over the TRPM1 channels $(\Delta V)$, or whether the extracellular resistance, $R_{\text {ext }}$, can influence $\Delta V$. In other words, one needs to compare this system when $R_{\mathrm{in} 2}$ is high and $R_{\mathrm{ext}}$ is low and vice-versa.

The relationship between $V_{2}$, the voltage at the secondary dendrites, $\Delta V, R_{\text {in } 2}$ and $R_{\text {ext }}$ can be calculated by means of the following equations:

$$
\begin{gathered}
V_{2}=i_{3} *\left(R_{e x t}+\frac{R_{G} R_{K}}{R_{G}+R_{K}}+R_{i n 2}\right), \\
i_{3}=\left(V_{3}-V_{4}\right) * \frac{\left(R_{G}+R_{K}\right)}{R_{G} R_{K}}, \\
V_{3}-V_{4}=\Delta V, \\
V_{2}=\Delta V * \frac{\left(R_{G}+R_{K}\right)}{R_{G} R_{K}} *\left(R_{e x t}+\frac{R_{G} R_{K}}{R_{G}+R_{K}}+R_{i n 2}\right) \\
=\Delta V * \frac{\left(R_{e x t}+R_{i n 2}\right) *\left(R_{G}+R_{K}\right)+R_{G} R_{K}}{R_{G} R_{K}} \\
\Delta V=V_{2} \frac{R_{G} R_{K}}{\left(R_{e x t}+R_{i n 2}\right)^{*}\left(R_{G}+R_{K}\right)+R_{G} R_{K}} .
\end{gathered}
$$

Eq. 10 shows that $R_{\text {in } 2}$ and $R_{\text {ext }}$ are fully interchangeable: the space clamp problem will be similar when either the intracellular or extracellular resistance is high (or any combination in between). Therefore, even though $\mathrm{ON}$ mBCs might have relatively small dendritic diameters, there might also be a high extracellular resistance in the rod spherule, which would contribute to the results shown here. Such high resistance has been suggested to exist in the cone pedicle and to determine interactions between horizontal cells and cones in the outer retina (Kamermans et al., 2001; Klaassen et al., 2012; Vroman et al., 2013; Vroman et al., 2014). In the rod spherule, it creates an impedance mismatch between the sites of synaptic input and the cell soma, preventing proper space clamp at depolarized potentials. 


\section{Discussion}

Here we show that voltage-gated $\mathrm{K}^{+}$channels, located at the dendritic tips of $\mathrm{ON} \mathrm{mBCs}$, act as a gain control mechanism for the rod-ON mBC synapse, by speeding up light responses of coupled cells and repolarizing their membrane potential in an intensitydependent fashion. We will next discuss the consequences of this organization in visual processing.

\section{Bipolar Cells Are Not Isopotential}

Most arguments about bipolar cells being isopotential come from experiments conducted on isolated neurons (Attwell et al., 1987; Lasater et al., 1984). However, the isolation procedure may lead to amputation of peripheral dendrites, since a high percentage of cells in these preparations that lack responses to glutamate (Lasater et al., 1984) and GABA (Kaneko et al., 1991). Even though anisopotentiality is usually thought of as a property of large CNS neurons, there are several examples in literature regarding compartmentalization of active conductances in bipolar cells. Some voltage-gated $\mathrm{K}^{+}$ channel subunits are preferentially expressed at the dendritic tips of murine rod bipolar neurons (Klumpp et al., 1995; Pinto and Klumpp, 1998), voltage-gated $\mathrm{Na}^{+}$channels were identified in goldfish cone-driven bipolar cell dendrites and somas (Zenisek et al., 2001), and large $\mathrm{Ca}^{2+}, \mathrm{Ca}^{2+}$-dependent $\mathrm{K}^{+}$and $\mathrm{Cl}^{-}$currents originate in the giant synaptic terminals of goldfish ON mBCs (Burrone and Lagnado, 1997; Kaneko et al., 1991; Kaneko and Tachibana, 1985; Okada et al., 1995; Sakaba et al., 1997; Tachibana et al., 1993; Zenisek and Matthews, 1997) and in rat rod bipolar cells (Singer and Diamond, 2003).

In agreement with this idea, our simulations show that due to the nature of the synaptic inputs to ON mBCs (mGluR6 at the dendrites contacting rods and EAAT5 at the dendrites contacting cones), the dendritic tips contacting rods might be slightly more depolarized than the cell soma, while the dendrites contacting cones would be slightly more hyperpolarized than the soma (not shown). This inhomogeneity in a small neuron such as the goldfish $\mathrm{ON} \mathrm{mBC}$ has important functional consequences, because it leads to a larger activation of dendritic $\mathrm{K}^{+}$channels at the sites of rod synaptic input as compared to the sites of cone input. This way, dendritic $I_{\mathrm{KV}}$ will be more efficient in regulating the gain of the rod-ON $\mathrm{mBC}$ synapse than in regulating the gain of the cone-ON mBC synapse, having a larger influence in visual processing at scotopic and mesopic levels.

\section{Dendritic $\mathrm{K}^{+}$Channels Are a Gain Control Mechanism}

The rod-bipolar cell synapse has high gain in order to allow large threshold responses in the scotopic range (Ashmore and Falk, 1980; Capovilla et al., 1987; Copenhagen et al., 1990; Falk, 1988). Such an amplification at this synapse is necessary because rod voltage 
responses at threshold are extremely small (Copenhagen and Owen, 1976; Fain, 1975; Fain, 1976), slow, and buried in noise (Field et al., 2005; Taylor and Smith, 2004). Amplification of rod signals increases the responses of second-order neurons, but it also implies in amplification of noise levels (Field et al., 2005; Taylor and Smith, 2004). Such amplification is however not necessary for light intensities that generate sizeable responses from rods and that stimulate cones. The gain of the rod-bipolar cell synapse is therefore not static and changes with stimulus intensity and/or background light levels (Ashmore and Falk, 1980; Yang and Wu, 1997): the more photons available, the lower the gain. One of the mechanisms responsible for the high gain of this synapse and for eliminating some of its noise is the mGluR6 cascade itself (Falk, 1988; Sampath and Rieke, 2004; Shiells, 1994; Shiells and Falk, 1995). The mechanism responsible for the gain decrease at higher light levels is unknown - for this purpose, multiple mechanisms could be employed, such as feedback from horizontal cells onto rods (Thoreson et al., 2008) and intrinsic regulation of the mGluR6 cascade (Snellman et al 2008).

We propose that one such mechanisms is the activation of voltage-gated $\mathrm{K}^{+}$ currents in the vicinity of synaptic input sites. In the dark, the mGluR6 pathway is activated in a sustained manner, keeping the TRPM1 channels in the ON mBC membrane almost closed. Since in this condition the tips of the dendrites are relatively hyperpolarized, $I_{\mathrm{KV}}$ is hardly activated. This makes the resistance of the tips of the dendrites higher. In this condition, a small modulation of the mGluR6 pathway will lead to signal transmission to the soma, since the resistance of the tip is balanced to the resistance of the secondary dendrite. At higher light levels, the mGluR6 pathway will be less activated, and the tips of the dendrites will depolarize. This will in turn activate $I_{\mathrm{KV}}$, and the overall result will be a reduction of the resistance of the tips. Because in this condition the balance between the resistance of the tips and the resistance of the secondary dendrites is less optimal, the signals from rods to the $\mathrm{ON} \mathrm{mBC}$ will be transmitted with lower gain. Interestingly, this system could also modify the gain of rod signals during light and dark adaptation, since voltage-gated $\mathrm{K}^{+}$conductances in $\mathrm{ON} \mathrm{mBCs}$ are enhanced by dopamine (Fan and Yazulla, 1999; Fan and Yazulla, 2001; Yazulla et al., 2001), and that dopamine levels are higher in the light-adapted retina (Djamgoz and Wagner, 1992; Witkovsky and Dearry, 1991).

This system has additional intriguing features. First, the interaction between dendritic $\mathrm{K}^{+}$channels and the rod-driven conductance shown here not only speeds up repolarization of the $\mathrm{ON} \mathrm{mBC}$ directly stimulated by light, but also contributes to signal spread within the network of coupled ON mBCs. The large convergence of rods onto ON $\mathrm{mBCs}$ and the fact that the latter are electrically coupled make them poor candidates for single-photon detectors, unlike mammalian rod-driven bipolar cells, since (i) photoreceptor convergence can potentially lead to a decrease in the influence of each single receptor onto the membrane potential of the second-order neuron (Falk, 1988), and 
(ii) electrical coupling decreases the flash sensitivity of individual cells due to current escape via the gap junctions (Hornstein et al., 2005). Rather, this combination of large receptive fields and transient responses would tune $\mathrm{ON} \mathrm{mBCs}$ for the detection of low spatial frequencies and middle to high temporal frequencies, which could in turn be beneficial for downstream neurons involved in motion detection.

Finally, although mammalian rod-driven bipolar cells are not electrically coupled, they share with $\mathrm{ON} \mathrm{mBCs} \mathrm{the} \mathrm{same} \mathrm{machinery} \mathrm{for} \mathrm{the} \mathrm{generation} \mathrm{and} \mathrm{gain} \mathrm{control} \mathrm{of} \mathrm{the}$ light response. In this respect, the results shown here are relevant for both mammalian and non-mammalian retinas. Because $\mathrm{K}^{+}$currents do not affect small $(2-5 \mathrm{mV})$ voltage responses, at very low light levels, $\mathrm{ON} \mathrm{mBCs}$ are allowed to integrate photons over larger periods. As more and more photons become available, the proposed mechanism will quickly change the gain of the synapse locally to prevent saturation, while allowing signals from other rods to activate the $\mathrm{ON} \mathrm{mBC}$ with the highest possible gain. Since the activation of these $\mathrm{K}^{+}$channels allows the membrane voltage to respond quicker to the changes in current flow (Mao et al., 1998; Mao et al., 2002), a consequence of this is that individual dendritic responses become shorter than the rod response itself, eliminating temporal redundancy in the neural code already at the first synapse. In fact, rod-driven $\mathrm{ON} \mathrm{BC}$ responses are much faster than rod light responses in both lower vertebrates and mammals (Field et al., 2005). 


\section{References}

Arai I, Tanaka M \& Tachibana M (2010). Active roles of electrically coupled bipolar cell network in the adult retina. J Neurosci 30: 9260-9270.

Ashmore JF \& Falk G (1980). Response of rod bipolar cells in the dark-adapted retina of the dogfish, Scyliorhinus canicula. J Physiol 300: 115-150.

Attwell D, Mobbs P, Tessier-Lavigne M \& Wilson M (1987). Neurotransmitter-induced currents in retinal bipolar cells of the axolotl, Ambystoma mexicanum. J Physiol 387: 125-161.

Bader CR, Bertrand D \& Schwartz EA (1982). Voltage-activated and calcium-activated curents studied in solitary rod inner segments from the salamander retina. J Physiol 331: 253-284.

Balasubramanian V \& Sterling P (2009). Receptive fields and functional architecture in the retina. J Physiol 587: 2753-2767.

Barry PH \& Lynch JW (1991). Liquid junction potentials and small cell effects in patchclamp analysis. J Membr Biol 121: 101-117.

Berntson A, Smith RG \& Taylor WR (2004). Postsynaptic calcium feedback between rods and rod bipolar cells in the mouse retina. Vis Neurosci 21: 913-924.

Berntson A, Smith RG \& Taylor WR (2005). Postsynaptic calcium feedback between rods and rod bipolar cells in the mouse retina. Vis Neurosci 21: 913-924.

Borges S \& Wilson M (1987). Structure of the receptive fields of bipolar cells in the salamander retina. J Neurophysiol 58: 1275-1291.

Burrone J \& Lagnado L (1997). Electrical resonance and Ca2+ influx in the synaptic terminal of depolarizing bipolar cells from the goldfish retina. J Physiol 505: 571-584.

Capovilla M, Hare WA \& Owen WG (1987). Voltage gain of signal transfer from retinal rods to bipolar cells in the tiger salamander. J Physiol 391: 125-140.

Carnevale NT \& Hines ML (2006). The Neuron Book. Cambridge University Press, Cambridge.

Copenhagen DR, Hemilä S \& Reuter T (1990). Signal transmission through the darkadapted retina of the toad (Bufo marinus) Gain, convergence and signal/noise. J Gen Physiol 95: 717-732.

Copenhagen DR \& Owen WG (1976). Functional characteristics of lateral interaction between rods in the retina of the snapping turtle. J Physiol 259: 251-282.

Djamgoz MBA \& Wagner H-J (1992). Localization and function of dopamine in the adult vertebrate retina. Neurochem Int 20: 139-191.

Dreosti E, Esposti F, Baden T \& Lagnado L (2011). In vivo evidence that retinal bipolar cells generate spikes modulated by light. Nat Neurosci 14: 951-952. 
Ellis KJ \& Duggleby RG (1978). What happens when data are fitted to the wrong equation? Biochem J 171: 513-517.

Euler T \& Masland RH (2000). Light-evoked responses of bipolar cells in a mammalian retina. J Neurophysiol 83: 1817-1829.

Fain GL (1975). Quantum sensitivity of rods in the toad retina. Science 187: 838-841.

Fain GL (1976). Sensitivity of toad rods: dependence on wavelength and background illumination. J Physiol 261: 71-101.

Falk G (1988). Signal transmission from rods to bipolar and horizontal cells: a synthesis. Prog Retinal Res 8: 255-279.

Fan SF \& Yazulla S (1997). Electrogenic hyperpolarization-elicited chloride transporter current in blue cones of zebrafish retinal slices. J Neurophysiol 77: 1447-1459.

Fan SF \& Yazulla S (1999). Suppression of voltage-dependent K+ currents in retinal bipolar cells by ascorbate. Vis Neurosci 16: 141-148.

Fan SF \& Yazulla S (2001). Dopamine depletion with 6-OHDA enhances dopamine D1receptor modulation of potassium currents in retinal bipolar cells. Vis Neurosci 18: 327-337.

Field GD, Sampath AP \& Rieke F (2005). Retinal processing near absolute threshold: from behavior to mechanism. Annu Rev Physiol 67: 491-514.

Gorcs TJ, Leranth C \& MacLusky NJ (1986). The use of gold-substituted silverintensified diaminobenzidine $(\mathrm{DAB})$ and non-intensified $\mathrm{DAB}$ for simultaneous electron microscopic immunoperoxidase labeling of tyrosine hydroxylase and glutamic acid decarboxylase immunoreactivity in the rat medial preoptic area. $\mathbf{J}$ Histochem Cytochem 34: 1439-1447.

Grant GB \& Dowling JE (1995). A glutamate-activated chloride current in cone-driven ON bipolar cells of the white perch retina. J Neurosci 15: 3852-3862.

Grant GB \& Dowling JE (1996). On bipolar cell responses in the teleost retina are generated by two distinct mechanisms. J Neurophysiol 76: 3842-3849.

Hack I, Peichl L \& Brandstätter JH (1999). An alternative pathway for rod signals in the rodent retina: rod photoreceptors, cone bipolar cells, and the localization of glutamate receptors. Proc Natl Acad Sci USA 96: 14130-14135.

Hausser M \& Roth A (1997). Estimating the time course of the excitatory synaptic conductance in neocortical pyramidal cells using a novel voltage jump method. J Neurosci 17: 7606-7625.

Haverkamp S, Grunert U \& Wassle H (2001). The synaptic architecture of AMPA receptors at the cone pedicle of the primate retina. J Neurosci 21: 2488-2500.

Hines ML \& Carnevale NT (1997). The NEURON simulation environment. Neural Comput 9: 1179-1209.

Hines ML \& Carnevale NT (2000). Expanding NEURON's repertoire of mechanisms with NMODL. Neural Comput 12: 995-1007. 
Hornstein EP, Verweij J, Li PH \& Schnapf JL (2005). Gap-junctional coupling and absolute sensitivity of photoreceptors in macaque retina. J Neurosci 25: 11201-11209.

Hu HJ \& Pan ZH (2002). Differential expression of K+ currents in mammalian retinal bipolar cells. Vis Neurosci 19: 163-173.

Ishida AT, Stell WK \& Lightfoot DO (1980) Rod and cone inputs to bipolar cells in goldfish retina. J Comp Neurol 191: 315-335.

Joselevitch C \& Kamermans M (2007). Interaction between rod and cone inputs in mixedinput bipolar cells in goldfish retina. J Neurosci Res 85: 1579-1591.

Kamermans M, Fahrenfort I, Schultz K, Janssen-Bienhold U, Sjoerdsma T \& Weiler R (2001) Hemichannel-mediated inhibition in the outer retina. Science 292: 1178-1180.

Kaneko A, Suzuki S, Pinto LH \& Tachibana M (1991). Membrane currents and pharmacology of retinal bipolar cells: a comparative study on goldfish and mouse. Comp Biochem Physiol 98C: 115-127.

Kaneko A \& Tachibana M (1985). A voltage-clamp analysis of membrane currents in solitary bipolar cells dissociated from Carassius auratus. J Physiol 358: 131-152.

Kaneko A \& Tachibana M (1987). GABA mediates the negative feedback from amacrine to bipolar cells. Neurosci Res Suppl 6: S239-S252.

Klaassen L, Fahrenfort I \& Kamermans M (2012). Connexin hemichannel mediated ephaptic inhibition in the retina. Brain Res 1487: 25-38.

Klooster J, Nunes CB, Yazulla S \& Kamermans M (2004). Postsynaptic localization of gamma-aminobutyric acid transporters and receptors in the outer plexiform layer of the goldfish retina: An ultrastructural study. J Comp Neurol 474: 58-74.

Klooster J, Studholme KM \& Yazulla S (2001). Localization of the AMPA subunit GluR2 in the outer plexiform layer of goldfish retina. J Comp Neurol 441: 155-167.

Klumpp DJ, Song EJ, Ito S, Sheng MH, Jan LY \& Pinto LH (1995). The Shaker-like potassium channels of the mouse rod bipolar cell and their contributions to the membrane current. J Neurosci 15: 5004-5013.

Kuo SP, Schwartz GW \& Rieke F (2016). Nonlinear spatiotemporal integration by electrical and chemical synapses in the retina. Neuron 90: 320-332.

Ladman AJ (1958). The fine structure of the rod-bipolar cell synapse in the retina of the albino rat. J Biophys Biochem Cytol 4: 459-466.

Lasater EM (1988). Membrane currents of retinal bipolar cells in culture. J Neurophysiol 60: $1460-1480$.

Lasater EM, Dowling JE \& Ripps H (1984). Pharmacological properties of isolated horizontal and bipolar cells from the skate retina. J Neurosci 4: 1966-1975.

Mao BQ, MacLeish PR \& Victor JD (1998). The intrinsic dynamics of retinal bipolar cells isolated from tiger salamander. Vis Neurosci 15: 425-438. 
Mao BQ, MacLeish PR \& Victor JD (2002). Relation between potassium-channel kinetics and the intrinsic dynamics in isolated retinal bipolar cells. J Comput Neurosci 12: $147-163$.

Mennerick S, \& Matthews G (1997). Ultrafast exocytosis elicited by calcium current in synaptic terminals of retinal bipolar neurons. Neuron 17: 1241-1249.

Mennerick S, Zenisek D \& Matthews G (1997). Static and dynamic membrane properties of large-terminal bipolar cells from goldfish retina: experimental test of a compartment model. J Neurophysiol 78: 51-62.

Mooij JEM \& Van den Berg TJTP (1983). The spectral shape of A2 visual pigments. Vision Res 23: 701-705.

Nadeau H \& Lester HA (2000). Two-compartment model for whole-cell data analysis and transient compensation. J Neurosci Methods 99: 25-35.

Nawy S, Copenhagen, DR (1987). Multiple classes of glutamate receptor on depolarizing bipolar cells in retina. Nature 325: 56-58.

$\mathrm{Ng}$ B \& Barry PH (1995). The measurement of ionic conductivities and mobilities of certain less common organic ions needed for junction potential corrections in electrophysiology. J Neurosci Methods 56: 37-41.

Oesch NW \& Diamond JS (2011). Ribbon synapses compute temporal contrast and encode luminance in retinal rod bipolar cells. Nat Neurosci 14: 1555-1561.

Okada T, Horoguchi H \& Tachibana M (1995). Ca2+-dependent Cl- current at the presynaptic terminals of goldfish retinal bipolar cells. Neurosci Res 23: 297-303.

Oltedal L, Veruki ML \& Hartveit E (2009). Passive membrane properties and electrotonic signal processing in retinal rod bipolar cells. J Physiol 587: 829-849.

Palmer MJ, Hull C, Vigh J \& Von Gersdorff H (2003a). Synaptic cleft acidification and modulation of short-term depression by exocytosed protons in retinal bipolar cells. $\mathrm{J}$ Neurosci 23: 11332-11341.

Palmer MJ, Taschenberger H, Hull C, Tremere L \&Von Gersdorff H (2003b) Synaptic activation of presynaptic glutamate transporter currents in nerve terminals. J Neurosci 23: 4831-4841.

Pang JJ, Gao F \& Wu SM (2004). Light-evoked current responses in rod bipolar cells, cone depolarizing bipolar cells and AII amacrine cells in dark-adapted mouse retina. J Physiol 558: 897-912.

Pinto LH \& Klumpp DJ (1998). Localization of potassium channels in the retina. Prog Retin Eye Res 17: 207-230.

Poznanski RR \& Umino O (1997). Syncytial integration by a network of coupled bipolar cells in the retina. Prog Neurobiol 53: 273-291.

Protti DA, Flores-Herr N \& Von Gersdorff H (2000). Light evokes Ca2+ spikes in the axon terminal of a retinal bipolar cell. Neuron 25: 215-227. 
Rieke F \& Rudd ME (2009). The challenges natural images pose for visual adaptation. Neuron 64: 605-616.

Saito T \& Kujiraoka T (1988). Characteristics of bipolar-bipolar coupling in the carp retina. J Gen Physiol 91: 275-287.

Sakaba T, Ishikane H \& Tachibana M (1997). Ca2+-activated K+ current at presynaptic terminals of goldfish retinal bipolar cells. Neurosci Res 27: 219-228.

Sampath AP \& Rieke F (2004). Selective transmission of single photon responses by saturation at the rod-to-rod bipolar synapse. Neuron 41: 431-443.

Saszik S \& DeVries SH (2012). A mammalian retinal bipolar cell uses both graded changes in membrane voltage and all-or-nothing $\mathrm{Na}+$ spikes to encode light. $\mathrm{J}$ Neurosci 32: 297-307.

Schaefer AT, Helmstaedter M, Sakmann B \& Korngreen A (2003). Correction of conductance measurements in non-space-clamped structures: 1. Voltage-gated $\mathrm{K}+$ channels. Biophys J 84: 3508-3528.

Scholes JH (1975). Colour receptors, and their synaptic connexions, in the retina of a cyprinid fish. Philos Trans R Soc Lond B Biol Sci 270: 61-118.

Schultz K, Janssen-Bienhold U \& Weiler R (2001). Selective synaptic distribution of AMPA and kainate receptor subunits in the outer plexiform layer of the carp retina. $\mathrm{J}$ Comp Neurol 435: 433-449.

Shen Y, Heimel JA, Kamermans M, Peachey NS, Gregg RG \& Nawy S (2009). A transient receptor potential-like channel mediates synaptic transmission in rod bipolar cells. J Neurosci 29: 6088-6093.

Shields CR, Tran MN, Wong RO \& Lukasiewicz PD (2000). Distinct ionotropic GABA receptors mediate presynaptic and postsynaptic inhibition in retinal bipolar cells. J Neurosci 20: 2673-2682.

Shiells RA (1994). Glutamate receptors for signal amplification. Curr Biol 4: 917-918.

Shiells RA \& Falk G (1995). Signal transduction in retinal bipolar cells. Prog Retin Eye Res 14: 223-247.

Shiells RA \& Falk G (1999). A rise in intracellular Ca2+ underlies light adaptation in dogfish retinal 'on' bipolar cells. J Physiol 514 ( Pt 2): 343-350.

Singer JH \& Diamond JS (2003). Sustained Ca2+ entry elicits transient postsynaptic currents at a retinal ribbon synapse. J Neurosci 23: 10923-10933.

Sjostrand FS (1998a). Structure determines function of the retina, a neural center. 1. The synaptic ribbon complex. J Submicrosc Cytol Pathol 30: 1-29.

Sjostrand FS (1998b). Structure determines function of the retina, a neural center. 2. The second, third and fourth circuits. J Submicrosc Cytol Pathol 30: 193-206.

Slaughter MM \& Miller RF (1981). 2-amino-4-phosphonobutyric acid: a new pharmacological tool for retinal research. Science 211: 182-185. 
Snellman J \& Nawy S (2002). Regulation of the retinal bipolar cell mGluR6 pathway by calcineurin. J Neurophysiol 88: 1088-1096.

Snellman J, Kaur T, Shen Y \& Nawy (2008). Regulation of ON bipolar cell activity. Prog Retin Eye Res 27: 450-463.

Spruston N, Jaffe DB, Williams SH \& Johnston D (1993). Voltage- and space-clamp errors associated with the measurement of electrotonically remote synaptic events. J Neurophysiol 70: 781-802.

Stell WK (1978). Inputs to bipolar cell dendrites in goldfish retina. Sens Processes 2: 339349.

Tachibana M, Okada T, Arimura T, Kobayashi K \& Piccolino M (1993). Dihydropyridine-sensitive calcium current mediates neurotransmitter release from bipolar cells of the goldfish retina. J Neurosci 13: 2898-2909.

Taylor WR \& Smith RG (2004). Transmission of scotopic signals from the rod to rodbipolar cell in the mammalian retina. Vision Res 44: 3269-3276.

Tessier-Lavigne M, Attwell D, Mobbs P \& Wilson M (1988). Membrane currents in retinal bipolar cells of the axolotl. J Gen Physiol 91: 49-72.

Thoreson, WB, Babai, N \& Bartoletti TM (2008). Feedback from horizontal cells to rod photoreceptors in vertebrate retina. J Neurosci 28: 5691-5695.

Trexler EB, Li W \& Massey SC (2005). Simultaneous contribution of two rod pathways to AII amacrine and cone bipolar cell light responses. J Neurophysiol 93: 1476-1485.

Umino O, Maehara M, Hidaka S, Kita S \& Hashimoto Y (1994). The network properties of bipolar-bipolar cell coupling in the retina of teleost fishes. Vis Neurosci 11: 533548.

Vroman R, Klaassen LJ, Howlett MH, Cenedese V, Klooster J, Sjoerdsma T \& Kamermans M (2014). Extracellular ATP hydrolysis inhibits synaptic transmission by increasing ph buffering in the synaptic cleft. PLoS Biol 12: e1001864.

Vroman R, Klaassen LJ \& Kamermans M (2013). Ephaptic communication in the vertebrate retina. Front Hum Neurosci 7: 612.

Witkovsky P \& Dearry A (1991). Functional roles of dopamine in the vertebrate retina. Prog Retinal Res 11: 247-292.

Witkovsky P \& Stell WK (1973). Retinal structure in the smooth dogfish, Mustelus canis: Light Microscopy of bipolar cells. J Comp Neurol 148: 47-60.

Wong KY, Cohen ED \& Dowling JE (2005). Retinal bipolar cell input mechanisms in giant danio. II. Patch-clamp analysis of on bipolar cells. J Neurophysiol 93: 94-107.

Yamada M \& Saito T (1997). Dual component in receptive field centre of bipolar cells in carp retina. Vision Res 37: 2331-2338.

Yamashita M \& Wassle H (1991). Responses of rod bipolar cells isolated from the rat retina to the glutamate agonist 2-amino-4-phosphonobutyric acid (APB). J Neurosci 11: 2372-2382. 
Yang X-L \& Wu SM (1997). Response sensitivity and voltage gain of the rod- and conebipolar cell synapse in dark-adapted tiger salamander retina. J Neurophysiol 78: 26622673.

Yazulla S, Studholme KM, Fan SF \& Mora-Ferrer C (2001). Neuromodulation of voltage-dependent $\mathrm{K}+$ channels in bipolar cells: immunocytochemical and electrophysiological studies. Prog Brain Res 131: 201-213.

Zenisek D, Henry D, Studholme K, Yazulla S \& Matthews G (2001). Voltage-dependent sodium channels are expressed in nonspiking retinal bipolar neurons. J Neurosci 21: 4543-4550.

Zenisek D \& Matthews G (1997). Calcium action potentials in retinal bipolar neurons. Vis Neurosci 15: 69-75. 